\title{
A Systematic Literature Review of Historic Garden Management and Its Economic Aspects
}

\author{
Cassandra Funsten, Valeria Borsellino *(1) and Emanuele Schimmenti (D) \\ Department of Agricultural, Food and Forest Sciences, Università degli Studi di Palermo, 90128 Palermo, Italy; \\ cassandra.funsten@unipa.it (C.F.); emanuele.schimmenti@unipa.it (E.S.) \\ * Correspondence: valeria.borsellino@unipa.it
}

Received: 31 October 2020; Accepted: 18 December 2020; Published: 21 December 2020

check for updates

\begin{abstract}
Historic gardens are important parts of humanity's built heritage within the designed landscape, providing many environmental, economic and socio-cultural benefits. Management is a key part of their conservation, perhaps the most difficult because it is costly, must be continual, and requires a skilled workforce. This systematic review looks at the literature addressing historic garden management, with special attention regarding the social, economic and environmental aspects of sustainability. Academic studies on this subject come from many different disciplines, making it both stimulating and fragmented. It is now time to consolidate these interdisciplinary efforts into a clear vision, including a framework of key themes and research methods so as to better coordinate efforts and make the information and innovation generated more accessible to the garden managers "in the trenches". With this aim, reviewed studies are classified according to 10 criteria: supply or demand orientation; management phase involved; primary sustainability processes addressed; geographic criteria; number of sites covered; policy documents referred to; kind of data collected; study methods employed; possibility of bias specifically regarding historic gardens; garden use. An analysis of these criteria shows that historic garden management literature focuses on describing the gardens themselves, with few studies interested in the people supporting them. Future research should follow recent policy documents' lead and pay more attention to community value and involvement.
\end{abstract}

Keywords: historic garden types; social, economic and environmental sustainability; urban landscape; heritage management; heritage value assessment; conservation planning; conservation policy; interdisciplinary approaches

\section{Introduction}

Historic gardens are precious natural and cultural heritage sites that provide many socio-cultural, environmental, and economic benefits. Because they are made up of living elements, they require constant, qualified, long-term management to ensure their survival. They also have very high fixed costs and are capital intensive. For this reason, management has continued to be one of the greatest challenges to their sustainable conservation and to guaranteeing all of the many benefits that they provide.

Before beginning, it bears asking: what exactly is intended by "historic garden management"? Although there is an ongoing academic discourse trying to pin down the term "management", it is generally understood as the process through which "organizations set and achieve their objectives by planning, organizing and controlling their resources" [1]. Thus, management can be understood as the carrying out of the objectives of external and internal stakeholders, in this case, the community, visitors, and owners. 
These management objectives have probably changed greatly over the lifetime of any historic garden. While once used primarily for individual pleasure, they are increasingly valued by society as a whole and maintained for their external sociocultural and environmental benefits, especially in the historic urban landscape [2]. The first modern documented guidelines regarding conservation-oriented garden management were written by Antoine Dézallier d'Argenville at the beginning of the 18th century, for the great French Gardens of André Le Nôtre [3]. At the same time that these and other royal gardens became important national symbols during the Imperial age, garden visiting developed hand-in-hand with the Grand Tour, a cultural trip around Europe taken by the upper-class as the capstone of their education [4]. The rise of garden visiting, especially in Great Britain, would change the focus of historic garden management from pleasing the estate's family to satisfying a widening public [2]. These two origins are emblematic of the two principal internal objectives guiding historic garden management today: conserving the site's cultural and natural heritage and satisfying visitor needs. Achieving both requires a great deal of interdisciplinary knowledge, especially if the two objectives are to complement and not contrast one another.

Heritage conservation management principles are defined by international guiding documents and treaties dating back to the Athens Charter of 1931 [5]. These documents sometimes distinguish between two facets of conservation: that of care (maintenance and management) and that of repair (restoration and reconstruction). Other guiding documents see the two as part of a continual conservation management process. It should be noted that the use of the term "maintenance" was more commonly used in 20th-century documents when historic gardens were valued as material heritage purely for their monument value, while the use of the term "management" grew as they also became valued for their immaterial heritage and cultural significance. Indeed, historic gardens may have inspired this development in how all cultural heritage is identified and valued [5]. It should also be noted that historic gardens are not always referred to specifically by that name. According to their focus, policy documents may also address historic gardens under different labels, including "historic" [6] or "culturally significant sites" [7], "living monuments" [8] or "cultural landscapes" [9]. Furthermore, there has been an evolution away from monument-centric terms that only indicate the material fabric of heritage towards terms that include intangible aspects as well [10]. This shift has been accompanied by a growing recognition of the community's role in landscape conservation and a change in the experts' role from gatekeeper to facilitator. In addition, heritage has been recognized as not only historically and culturally important but also an essential factor in promoting sustainable development and wellbeing. Heritage conservation is a key policy point of documents such as the United Nations (UN) Sustainable Development Goals [11]-Target 11.4, "Strengthen efforts to protect and safeguard the world's cultural and natural heritage". This emphasis on sustainability can also be seen in the European Landscape Convention's definition of landscape management as "action, from a perspective of sustainable development, to ensure the regular upkeep of a landscape, so as to guide and harmonize changes which are brought about by social, economic and environmental processes" [9]. Thus, we can conclude that historic garden management must be operational, continual and sustainable; it involves multiple stakeholders, and most of all, must be adaptive. In the true sense of the term practice, it is never completed and always improving. That is why it is especially useful to conceive of historic garden management as a cyclical process that loops through a strategic phase, an operational phase and an assessment phase. The strategic phase involves defining long term stakeholders, significance, responsibilities and constraints; the operational phase is carried out within a given time frame and involves short-term actions, contracts and actors directly involved in management; the assessment phase regards the continuative monitoring of goal achievement, critical issues and policy implementation [12]. This vision of a multiphase conservation management process is common throughout operational guiding documents such as the United Nations Educational, Scientific and Cultural Organization (UNESCO) World Heritage List Operational Guidelines [13], the Australia/International Council on Monuments and Sites (ICOMOS) Burra Charter for Places of Cultural Significance [7], Natural England and English Heritage's Guidance Notes [14] and The United 
States of America (USA) Department of the Interior's Guidelines for the Management of Cultural Landscapes [15].

However, the ideal vision proposed in these policy documents often does not find its way into practice. National, regional and municipal planning measures fail to support historic gardens because they are out of date or because historic gardens fall between the more easily identifiable categories of architectural and natural heritage. Without more support, owners and managers are hard-pressed to keep up with even the day-to-day operations of their property, and gardens can easily slide into decay. Specifically, they struggle with financial resources [16,17], human capital [17-21] and information management [22,23]. Many have undergone a change in ownership from private estate to the public park, entailing a loss of compositional legibility; relationship with internal architecture and surrounding rural or urban context; number and diversity of botanical, architectural and decorative elements; agricultural or productive areas; continuous qualified care by the same gardeners in favor of discontinuous municipal gardeners or external firms; altered or destroyed views and vistas of the surrounding landscape [12]. This all erodes the garden's identity, an intangible value strongly linked to the character, spirit of the place, and significance, at the heart of conservation theory [24].

In order to safeguard both public [12] and private [22] historic gardens, efficient management tools and strategies need to be developed and evaluated that specifically address social, economic and environmental sustainability. Academic interest in this topic began in the $1980^{\prime} \mathrm{s}$, around when the Florence Charter officially identified historic gardens as living monuments [8]. The first decades of research generally focused on establishing the broader merits and principles of historic garden conservation. Around the time the European Landscape Convention was ratified in 2000, the best practice conservation guidelines mentioned above had been established. This was when the academic discourse began to assert itself and to branch out. In addition to the essays and historical case studies from Art and Architecture historians that were already being produced, contributions from many other fields began to appear. An early comprehensive review of historic garden management was published by Clare Askwith in 1999. However, in her article, "The economic contribution of historic parks, gardens and designed landscapes: a review of existing data and research recommendations for future research"[16], she must rely on a great deal of gray or flawed literature and can only address the United Kingdom (UK). Askwith concludes that information is lacking in everything from basic stocktaking, to historic gardens' impact as tourist attractions, to their role in local area economic regeneration, and finally their valuation as non-market goods.

Since Askwith's article, research has continued to branch out to new geographic areas and new disciplines. Researchers are increasingly interested in historic gardens' contributions to sustainability, and not just their material conservation. They also benefit from more historic gardens being recognized, restored and functioning, thus providing a wider selection of study subjects. Today, the literature is spread out among many diverse academic fields, including Applied Botany; Communications; Environmental Valuation and Appraisal; Heritage Studies; Horticulture; Landscape Architecture; Tourism Studies; and Urban Studies. Each applies its own particular perspectives and methods. Although rich with possibility, the resulting fragmentation impedes a clear vision of the current state of historic garden management studies and the various research tools available.

In order to make sense of such a varied corpus, this systematic literature review categorizes historic garden management publications according to 10 different criteria, including supply or demand orientation, management phase involved; primary sustainability processes addressed; geographic criteria; number of sites covered; policy documents referred to; kind of data collected; study methods employed; the possibility of bias specifically regarding historic garden study; historic garden use. The resulting groups reveal trends in the literature as well as the most significant gaps. Through them, this complex interdisciplinary field is mapped out, and insight is gained on the range of methods and research tools used to understand historic garden management and assess the many contributions made by historic gardens to social, economic and environmental sustainability. 


\section{Materials and Methods}

This article is based on a systematic review of records indexed in Scopus and Web of Science (WoS) and follows the preferred reporting items for systematic reviews and meta-analyses (PRISMA) guidelines [25] (Table 1). Initial trial search queries with various keywords began in January 2020, and the final verified search was carried out in each database on 15 October 2020. The search query used in Scopus was: (TITLE (historic* AND garden* AND management OR econ*) OR TITLE-ABS-KEY ("historic* garden*" AND management OR maintenance OR upkeep OR econ*)). The search query used in Web of Science was: TITLE: ((historic* garden*) AND (management or econ*)) OR TOPIC: ("historic* garden*") AND TOPIC: (management OR maintenance OR econ*). The obligatory term "historic garden" was chosen in order to concentrate directly on research that identified itself as pertaining to historic gardens, as opposed to implicitly connected research under other related labels (i.e., cultural landscapes, designed landscapes, historic parks, etc.). The optional keywords management, maintenance and upkeep, were chosen in order to capture as wide a sample of management-related articles as possible, with keywords commonly used in relevant policy documents. The keyword econ* was added after initial trial searches failed to collect economic literature in the two chosen databases. Documents were considered in any language, and Google translator was used to aiding the reading of studies written in languages other than English, Italian or French. The initial Scopus search yielded 57 documents, and the initial Web of Science search yielded 31 documents. Twenty-seven records were repeated in both databases, making the combined list of documents under consideration 61 . The identified publications were then screened based on their title and abstract to make sure that they focused on the management issues of historic gardens. Six publications were excluded at this point because they were inaccessible (5) or off-topic (1). Those that passed the screening were then accessed and read in their entirety. At this stage, another 5 articles were excluded because they were off-topic, repeated research published in another document within the review or was a book in which separate chapters had already been counted in the review. Finally, the remaining 50 documents were included in the historic garden management literature review.

Table 1. Document search and selection process.

\begin{tabular}{|c|c|c|}
\hline Systematic Review Step & Information Flow & Records Excluded and Reasons for Exclusion \\
\hline Identification & $\begin{array}{l}\text { Records identified via Scopus search } \\
\text { (no. }=57) \\
\text { Records identified via WoS search } \\
\text { (no. }=31)\end{array}$ & Duplicates removed $($ no. $=27$ ) \\
\hline Screening & $\begin{array}{l}\text { Records screened based on titles } \\
\qquad(\text { no. }=61)\end{array}$ & $\begin{array}{c}\text { Records excluded based on title screening (no. = 6): } \\
\text { Binney and Hills, 1979-inaccessible; } \\
\text { Wright, 1979—inaccessible; } \\
\text { Koylu and Karacor, 2010—inaccessible; } \\
\text { Ishikawa, 2014—inaccessible; } \\
\text { Aaltonen, Ahola, and Artto, 2017—off-topic; } \\
\text { Ruiz, 2020—inaccessible. }\end{array}$ \\
\hline Eligibility & $\begin{array}{l}\text { Full-text articles assessed for eligibility } \\
\qquad \text { (no. }=55)\end{array}$ & $\begin{array}{c}\text { Full-text articles excluded (no. = 5): } \\
\text { Negbi, 1991—off-topic; } \\
\text { Brine, 2002—-thesis whose results are published in } \\
\text { an included study; } \\
\text { Natale, Pulga and Guarino, 2010—off-topic; } \\
\text { Papafotiou and Kanellou, 2010_off-topic; } \\
\text { Harney, 2014—Book with individual chapters } \\
\text { separately identified. }\end{array}$ \\
\hline Inclusion & $\begin{array}{l}\text { Studies included in the } \\
\text { systematic review } \\
\text { (no. }=50)\end{array}$ & \\
\hline
\end{tabular}

Data were collected on each publication by reading the full text and classifying it according to the following criteria: supply or demand orientation; management process phase involved; sustainability themes addressed (social, economic, or environmental); geographic characteristics of the study (scale, 
country, continent); number of sites investigated; kind of information gathered and communicated (empirical or theoretical); eventual policy references; research instruments; possibility of bias in the study specifically regarding historic garden research; garden use addressed, i.e., general, public, tourist, or private (Table 2). Bias is assessed according to whether definitions and principles in the reviewed study are taken from named policy documents and whether the information is empirically gathered. 1 point is given for each parameter, with a possible bias score ranging between 0 and 2 .

Table 2. Research questions, data collection criteria, and classification categories.

\begin{tabular}{|c|c|c|}
\hline Research Question & Data Criteria & Categories \\
\hline \multirow[t]{3}{*}{$\begin{array}{c}4 . \\
\text { What geographic trends can be identified? }\end{array}$} & Geographical scale & $\begin{array}{l}\text { Local—single site to municipal; } \\
\text { Regional-provincial to regional; } \\
\text { National—nation-wide; } \\
\text { International—continental to world. }\end{array}$ \\
\hline & Country & Given by name. \\
\hline & Continent & Given by name. \\
\hline $\begin{array}{l}5 . \\
\text { What is the coverage of each study? }\end{array}$ & Site no. & The number of sites studied. \\
\hline $\begin{array}{c}8 . \\
\text { What research methods and instruments are } \\
\text { used? }\end{array}$ & Method & Given by name. \\
\hline $\begin{array}{c}9 . \\
\text { Bias score }\end{array}$ & Bias & $\begin{array}{l}1 \text { point for policy documents cited; } 1 \text { point for } \\
\text { empiric data; total score } 0-2 \text {. }\end{array}$ \\
\hline $\begin{array}{l}10 . \\
\text { How is historic garden management } \\
\text { research distributed according to garden } \\
\text { use? How does use affect the } \\
\text { above-mentioned criteria? }\end{array}$ & Use & $\begin{array}{c}\text { General-regards all historic gardens; } \\
\text { Public-regards publicly managed and funded } \\
\text { historic gardens that are freely accessible; } \\
\text { Tourist-regards historic gardens that generate } \\
\text { some revenue through entrance fees and } \\
\text { visitor services; } \\
\text { Private-regards historic gardens that are not } \\
\text { generally accessible to the public and are } \\
\text { primarily enjoyed by their owners. }\end{array}$ \\
\hline
\end{tabular}

${ }^{*}$ As defined by Cazzani et al., 2019 [12]; ${ }^{+}$as defined by Dempsey et al., 2009 [26]. 


\section{Results}

The studies in the systematic review include 30 research articles, 2 literature reviews, 12 conference papers and 6 book chapters. The specifics of each study can be found in Appendix A, where publications are divided by group, listed in chronological order, and briefly described according to this review's criteria.

The research articles and reviews are published in 20 different journals. Journals with more than 1 article on historic garden management include Urban Forestry and Urban Greening (4 articles); Acta Horticulturae (3 articles); Englera (2 articles); Journal of Cultural Heritage (2 articles); Landscape and Urban Planning (2 articles); Landscape Research (2 articles); Ornamental Horticulture ( 2 articles); Sustainability (2 articles). Many of these journals declare interdisciplinary aims and scopes [27-30], indicating that historic garden studies are well suited to this kind of approach.

Conference proceedings that feature contributions more than once, in any year, include proceedings of the Italian Botanical Society, published in Italian Botanist (5 papers); proceedings of the International Society for Horticultural Science, published in Acta Horticulturae (2 papers); proceedings of the International Society of Photogrammetry and Remote Sensing, published in the ISPRS Archives (2 papers). While the first two venues concerning botany and horticulture are expected, the multiple appearances of historic garden research in ISPRS conferences is interesting. The Society is dedicated to "information from imagery" [31], testifying to both the visual nature of historic gardens and the important role information acquisition and organization plays in their management.

As for book chapters, three of the six chapters are from Gardens and Landscapes in Historic Building Conservation, edited by Marion Harney [32], while the remaining three are in different books. While the former is entirely dedicated to historic gardens, these other volumes address historic constructions [33], innovations in tourism studies [34], and cultural urban heritage studies [35].

Whether academic journal, conference or book, all of these sources indicate a trend towards interdisciplinary research and younger research fields such as Landscape Studies, Urban Heritage and Tourism Studies. This should encourage historic garden scholars to look beyond their specific field and to connect their work to larger interdisciplinary issues. Not only would historic garden research gain greater exposure, but it would also become relevant to a wider audience.

The following sections discuss each of the research criteria individually. When necessary, conceptual criteria are specifically defined for this study. Then, the distribution of the studies by category is discussed. Finally, each criterion's section concludes with the main findings to emerge from its analysis. The last Section 3.10, goes most in-depth, revisiting each of the nine previously explored criteria according to garden use.

\subsection{Supply vs. Demand Analysis}

The studies are categorized according to supply or demand orientation. The difference between a supply or a demand-oriented study is determined based on whether reality is viewed from the garden owner/manager's perspective or from the visitor's perspective. Supply studies evaluate the gardens themselves as economic, cultural and environmental assets. Demand studies evaluate visitor needs/wants, characteristics, behavior, movement and spending as well as the non-use value attributed to the site by those who wish for the garden to exist, even if they don't visit (existence and bequest value). In this literature review: 41/50 studies are supply-oriented, 4/50 are demand-oriented, and 5/50 look at both supply and demand. The four studies focusing only on demand [34,36-38], and the five considering both [16,19,39-41] are particularly interested in the economic survival of historic gardens and understand that resources come from satisfied visitors in both public and private contexts. Rostami et al. [36], Saeed et al. [38] and Silva and Carvalho [34] use survey questionnaires in order to understand the profile, behavior and satisfaction of visitors. As de Oliveira Paiva, de Brito Sousa and Carcaud [41] explain in their recent review, this form of inquiry is common in the field of Tourism and Leisure Studies when evaluating market segments and attractions [41]. Todt, Herder and Dabija [37] discuss the economic impact of heritage conservation by citing global tourism board statistics. Other methodologies coming 
from the field of Resource Economics and Appraisal are presented by Askwith in her review [16]. In general, these seek to estimate the value of non-market public goods and compare that value to spending. Boisset [19] also notes the public amenity value of historic gardens. Finally, both Gratani [40] and Luz, Paiva, and Alves [39] make a point of including visitor information and attributed value in their case studies.

Grouping garden studies by supply vs. demand shows that the former is vastly favored. This may indicate that historic garden researchers are much more focused on the cause of protecting historic gardens themselves than on understanding the people who maintain, visit or value them. However, an understanding of demand not only allows gardens to better attract and satisfy paying visitors, but it is also important in holding institutions and professionals accountable for their allocation of resources, efficiency in meeting objectives and equity in serving a diverse public. For these reasons, demand (often phrased as community value) is increasingly emphasized in heritage policy [5] and should inform all historic garden conservation management plans.

\subsection{Management Phase}

Cazzani et al.'s management process flowchart (Figure 1) is used as a guide in separating the reviewed studies by management process. Cazzani et al. [12] bases their synthesis on the management processes and documentation required by UNESCO World Heritage Sites, The USA National Park Service, and the United Kingdom (UK)'s National Trust. Their vision of the management process is cyclical, moving from a strategic level to an operational level to an assessment level. At times, there is a fine line between the first phase and the last. When authors are proposing a new project, even hypothetically, their study is seen as strategic. When authors intend to evaluate what is already present, their work is categorized as an assessment.

In our literature review: $22 / 50$ of the studies are categorized as involving the strategic phase; $4 / 50$ are categorized as involving both the strategic and operational phases; $3 / 50$ are classified as involving the operational phase; $21 / 50$ are classified as involving the assessment phase.

Thus, this classification by management phase shows that the literature is split between the strategic phase and the assessment phase, with fewer operational management studies and combined strategic to operational phase studies. Both the strategic phase at the beginning of a project and the assessment phase at the end more easily lend themselves to research investigation. These are also often the phases where documentation is required by an outside institution, such as UNESCO for World Heritage Sites. However, the three articles that do treat the operational management phase all discuss an essential aspect of garden management: the too often overlooked role of skilled gardeners. Albericci's [18] discussion of the lack of skilled gardeners and professional training in Italian University Botanical Gardens, Thoday's [20] discussion of science and craft in garden management and Thorne's [42] guide on contracts and costs in historic garden management all address this key aspect. This labor issue also appears in Pérez-Urrestarazu et al.'s study of water irrigation efficiency [43] within the assessment management studies. In this case, the authors determine that a high number of people and work hours are dedicated to irrigation in their studied garden and hope to improve management and operation costs by implementing better planning and automation. Some studies also explicitly aim to help garden staff work more efficiently through better information management $[12,22,23,44]$ or by establishing clear protocols [45]. 


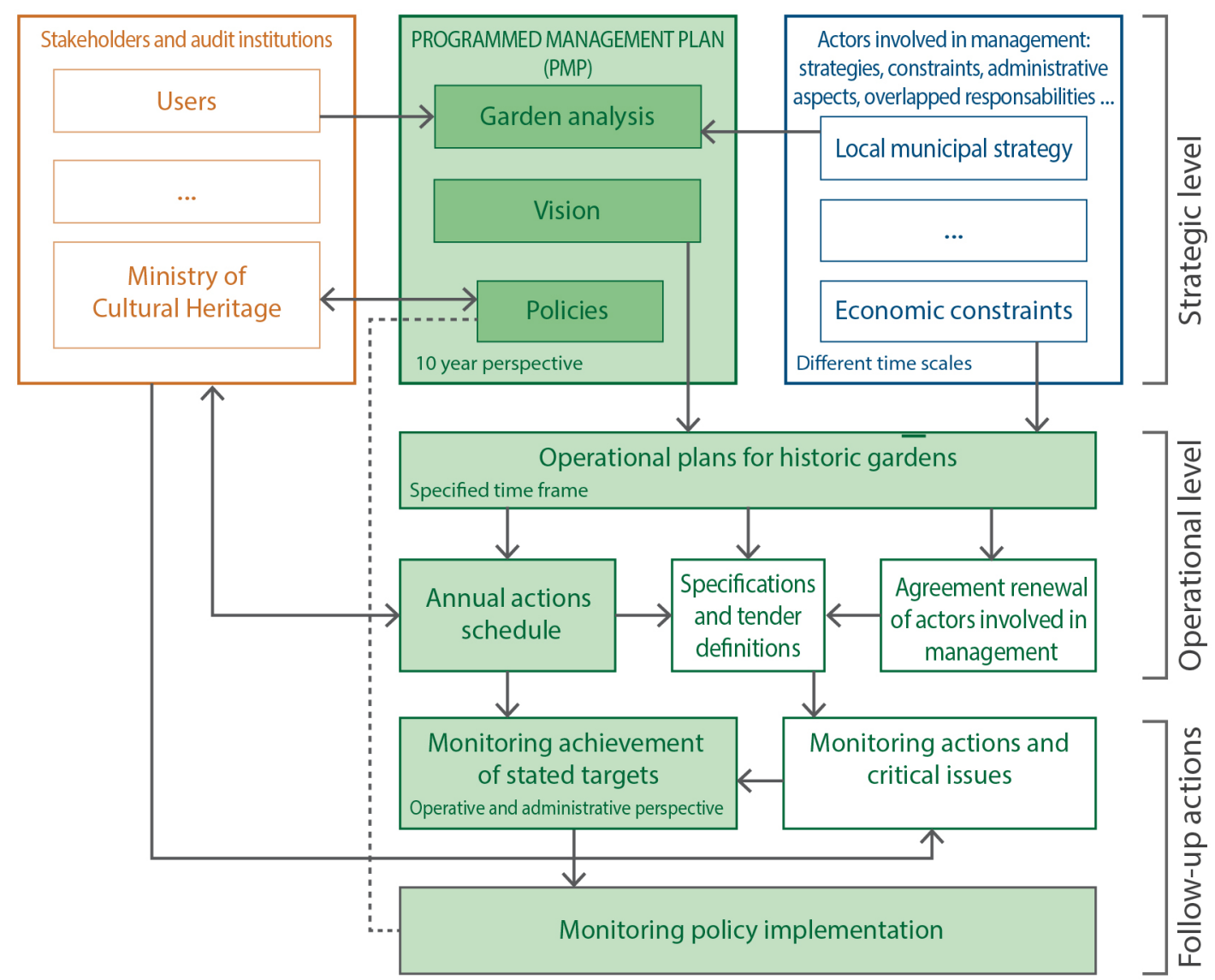

Figure 1. Flow chart of the decisional and operational aspects of the management of a historic garden, elaborated from Cazzani, Zerbi and Brumana (2019) [12], p. 295.

\subsection{Sustainability}

Based on the European Landscape Convention's definition of landscape management as guiding and harmonizing social, economic, and environmental processes [9], each study is classified by which of these processes is principally addressed. Social sustainability is defined as pertaining to community equity, cohesion and wellbeing, according to Dempsey et al., 2009 [26]. For simplicity's sake and conformity with the aforementioned Convention, this review includes cultural and political/institutional sustainability within social sustainability. However, it should be noted that some definitions of social sustainability separate these aspects (cf. Rostami et al. [36] from this review as well as [11,46,47]). A natural subdivision of social sustainability is particularly evident in the tourism garden category, discussed later. Definitions of economic and environmental sustainability are much less problematic. For this review's purposes, they are defined as the continued viability of the economic or environmental system supporting the studied historic garden(s).

In our literature review: 29/50 of studies primarily regard social sustainability; 5/50 of the studies primarily regard economic sustainability; $10 / 50$ of the studies primarily regard environmental sustainability; $5 / 50$ of the studies equally regard social and environmental sustainability; $1 / 50$ of the studies equally regard economic and social sustainability.

According to this categorization of the reviewed studies, it seems that historic gardens make their most important contributions to social sustainability. Both social sustainability and the related subject of cultural ecosystem services are notoriously understudied, and the debate is still quite open on how to measure them [48]. In light of the predominance of social sustainability themes in the literature, historic gardens might provide an ideal laboratory. Indeed, many studies in this review value plants or plant communities as much or more for their socio-cultural value [45,49-52] as for their environmental 
value. A fine line defines these studies' primary sustainability interest; however, the authors often purposefully emphasize social sustainability importance over environmental sustainability importance.

Another important consideration to emerge from this categorization is the evident lack of articles regarding economic sustainability. As several authors have noted, almost all historic gardens struggle to make ends meet $[16,17,22]$. Therefore, research that documents and analyzes the economic sustainability of historic gardens is vital. Finally, regarding environmental sustainability, the studies in this category mainly address historic gardens' roles in maintaining biodiversity. They show that historic gardens provide habitat for both important native species as well as the cultural relicts that have almost disappeared along with traditional agricultural landscapes [53,54]. The conservation of grassland/meadow species $[49,55,56]$ is found to be just as important as the conservation of tree species $[45,50,52]$. Two articles spoke about the water cycle [43,57]. Only one article spoke about historic gardens' impact on the urban climate [51].

\subsection{Geographic Distribution}

Studies are classified by various geographic criteria, including the scale, country, and continent under investigation. In terms of scale: $22 / 50$ of the studies are local; $6 / 50$ of the studies are regional; $16 / 50$ of the studies are national; $6 / 50$ of the studies are international. Country classifications after the removal of international studies are shown in Table 3. As for continents: 33 studies regard Europe (plus 1 of the international studies); 8 are in Asia, 1 is in Africa, 1 is in North America, and 1 is in South America. Regarding the nationality of the literature, the top 5 represented countries are Italy with a significant lead (13/44), followed by Germany (5/44), Iran (4/44), the UK (4/44), and Portugal (3/44).

What emerges most in this category is a preference for local or national scaled studies and a growing amount of literature coming from outside Europe. Local studies are more easily carried out, especially since garden history scholars tend to be specialized in a particular geographic area. National scale studies have the advantage that they can be most easily compared to standardized tourism statistics. While various researchers cite Great Britain as a leader in historic garden conservation, it is interesting to observe that the UK does not dominate the literature review. It should be noted that this criterion is particularly influenced by the two databases selected for this review, Scopus and WoS. Although both include scientific journals from various geographic areas and in various languages, all indexed publications must meet each database's standards. Grey literature and smaller scientific journals are left out. Great Britain and other countries may appear less important in this review's ranking because more of their research is published in these unobserved sources. Furthermore, the chosen keywords' focus on historic gardens rather than historic estates in their entirety may influence the selection. In any case, it seems that a wider range of geographic regions is beginning to participate in historic garden research at an international level. As noted by Silva and Carvalho [34], British data for garden tourism is often used as a benchmark in other contexts, without considering possible geographic or socio-cultural differences. In this respect, the contributions from Rostami et al. [36] and Saeed et al. [38] are particularly interesting because they show visitor profiles in a totally different cultural and climatic context, that of southwest Asia.

\subsection{Site Coverage}

Site coverage is defined as the number of locations treated in each study. If there are multiple sampling sites within one historic garden site, studies are categorized according to the garden sampling level. If the different sampling sites are spread out (e.g., throughout a city), each site is counted separately. 
Table 3. Distribution of study locations by country.

\begin{tabular}{|c|c|c|}
\hline Country & No. Studies & References \\
\hline Italy & 13 & $\begin{array}{c}\text { Albericci, } 2006 \text { [18]; } \\
\text { Cappelletti, 2006 [58]; } \\
\text { Cavagnero and Revelli, 2009 [57]; } \\
\text { Cazzani, Zerbi and Brumana, 2019 [12]; } \\
\text { Ciaffi, et al., 2018 [45]; } \\
\text { Gratani, 2006 [40]; } \\
\text { Gullino, Devecchi and Larcher, } 2020 \text { [59]; } \\
\text { Gullino, Larcher and Devecchi, } 2010 \text { [52]; } \\
\text { Malinverni, Chiappini and Pierdicca, } 2019 \text { [44]; } \\
\text { Meda and Rinaldi, 2006 [17]; } \\
\text { Nascimbene and Salvadori, 2008 [60]; } \\
\text { Prigioniero et al., 2020 [54]; } \\
\text { Tisi, 2006 [61]; }\end{array}$ \\
\hline Germany & 5 & $\begin{array}{l}\text { Bergande and Markstein, } 2013 \text { [62]; } \\
\text { Kowarik and Wohlgemuth, } 2006 \text { [49]; } \\
\text { Krosigk, } 1987 \text { [63]; } \\
\text { Kümmerling and Müller, } 2012 \text { [56]; } \\
\text { Maurer, Peschel and Schmitz, } 2000 \text { [55]; }\end{array}$ \\
\hline Iran & 4 & $\begin{array}{l}\text { Khalilnezhad, } 2017 \text { [64]; } \\
\text { Mahdizadeh and Rajendran, } 2018 \text { [65]; } \\
\text { Mahmood and Nasim, } 2012 \text { [66]; } \\
\text { Rostami et al., } 2015 \text { [36]; }\end{array}$ \\
\hline UK & 4 & $\begin{array}{l}\text { Askwith, } 1999 \text { [16]; } \\
\text { Boisset, } 1980 \text { [19]; } \\
\text { Brine and Feather, 2010 [46]; } \\
\text { Thorne, } 2014 \text { [42]; }\end{array}$ \\
\hline Portugal & 3 & $\begin{array}{c}\text { Alves et al., } 2019 \text { [33]; } \\
\text { Arteaga et al., } 2020 \text { [53]; } \\
\text { Silva and Carvalho, } 2019 \text { [34]; }\end{array}$ \\
\hline Austria & 1 & Mang, 2013 [67]; \\
\hline Brazil & 1 & Luz, Paiva, and Alves, 2017 [39]; \\
\hline Croatia & 1 & Obad Šćitaroci et al., 2019 [35]; \\
\hline Denmark & 1 & Hansen, Thomsen and Rasmussen, 2014 [50]; \\
\hline Egypt & 1 & Abdel-Rahman, 2016 [68]; \\
\hline France & 1 & Vissac, 2005 [69]; \\
\hline India & 1 & Wahurwagh and Dongre, 2015 [70]; \\
\hline Israel & 1 & Burmil, 2000 [71]; \\
\hline Japan & 1 & Oishi, 2019 [51]; \\
\hline Norway & 1 & Gao and Dietze-Schirdewahn, [10]; \\
\hline Pakistan & 1 & Saeed et al., 2017 [38]; \\
\hline Romania & 1 & Ionescu, Iliescu and Dumitrascu, 2010 [72]; \\
\hline Spain & 1 & Pérez-Urrestarazu et al., 2018 [43]; \\
\hline Sweden & 1 & Flinck, 2016 [73]; \\
\hline USA & 1 & Halbrooks, 2005 [74]. \\
\hline
\end{tabular}

$38 / 50$ of the studies identify specific investigated sites. Although the number of sites per study ranged from 1 to 201, the majority of studies choose only a few locations (the median is 3 ). This is motivated by the large number of case studies in the literature and the large amount of time necessary to adequately investigate any historic garden. Case studies, in particular, must include a historical and 
current site analysis as preliminary steps, necessitating archival, botanical and architectural skills as well as time. Those studies with more than 10 sites $[10,17,22,49,51,52,55,68]$ are all either field surveys or survey questionnaires. Although still quite time intensive, these research methods can more easily cover many sites. While case studies provide essential information for single projects, surveys with ample coverage are invaluable for establishing statistically valid benchmarks.

\subsection{Historic Garden Policy—Guidelines and Legislation}

As discussed in the introduction, there is a rich body of international policy governing the conservation of natural and cultural heritage that has evolved and changed since the 1960s. This includes the guiding documents, i.e., non-binding statements of best practices or intents, emanated by such international institutions as the UN, UNESCO and ICOMOS, or national bodies such as English Heritage or the USA National Park Service. It also includes binding international treaties and laws, which often protect historic gardens as a side effect while concentrating on other matters (especially heritage protection, environmental protection and humanitarian rights). The policy documents that were referenced or named in each study are listed and ranked in Table 4, so as to better understand the conservation principles and definitions guiding authors. National planning law has been lumped together, as an analysis of each country's specific legislation goes beyond the scope of this study. On the contrary, national guiding documents have been included, as they are also often referred to by studies outside their country of origin. Some studies cite multiple policy documents.

$13 / 50$ of the literature cites national planning and conservation laws. Indeed, national legislation has the most potential to protect or to expose historic gardens. The Florence Charter follows, with 11/50 citations. This is unsurprising because the Florence Charter is the first document to explicitly recognize historic gardens as cultural heritage and define the terms and objectives of their conservation. The World Heritage Convention is next, with $10 / 50$ citations. This testifies to how important UNESCO is in promoting and conserving the heritage of universal value. In fact, many studies in this review are conducted at World Heritage sites. Furthermore, the World Heritage Operational Guidelines are separately cited as a guide for conservation management planning [12,35], even for sites that are not part of the World Heritage List. It should be noted that some of the studies that do not refer to specific policy documents seem to have a working knowledge of conservation policy, demonstrated by the use of standard terms such as "fabric", "heritage", "historic", "significance", "integrity", "interpretation" and "authenticity". Because the understanding and interpretation of these terms change over time, relevant policy documents defining them should always be cited.

On the whole, the policy analysis shows that authors are critical of national planning and conservation policy's failure to sufficiently recognize and conserve historic gardens. Furthermore, the selection of commonly cited policy documents is much too narrow and dated in the reviewed literature. While the policy cited in the entire corpus is moderately comprehensive, only national planning and conservation law, the Florence Charter and the World Heritage Convention are cited more than 10 times. The remaining documents cited more than once were all emitted by the year 2000, while most of the important evolutions in policy regarding community involvement, sustainability and urban heritage occurred afterward.

\subsection{Type of Information Analyzed}

Publications are categorized by whether they are based on empirical or theoretical investigations. Empirical studies must be based on direct observation at a specified place and time. However, the information collected can be descriptive, qualitative or quantitative. Theoretical studies are those not based on direct experience at a specified place and time, i.e., if the authors are speaking from real-world experience, they do not specify when and where.

$42 / 50$ of the studies in this review are based on empirical observation, and 8/50 are theoretical discussions. This predominance of empirical studies is expected, as scientific journals generally reserve most of their pages for empirically based research. Theoretical discussions are all published before 
2015 , indicating that these early studies aimed to establish the underlying philosophy, terms, and best practices of historic garden management, paving the way for later empirical work.

\subsection{Study Methods}

Study methods used to research historic garden management are divided into the following general categories: case studies; biological field surveys; discussions; survey questionnaires or interviews; deoxyribonucleic acid (DNA) sequencing; policy analysis; review (in turn covering economic analysis and tourism statistics); hydraulic modeling; performance indicator analysis; geologic field survey. Each publication is classified by its primary study method in Table 5 .

Case studies make up 20/50 of the literature, followed by biological field surveys (8/50), discussions (7/50), survey questionnaires or interviews (6/50), DNA sequencing (2/50), policy analysis $(2 / 50)$, review of economic analysis $(1 / 50)$, review of garden tourism $(1 / 50)$, hydraulic modeling $(1 / 50)$, performance indicator analysis (1/50), and geologic field survey (1/50).

Case studies are so predominant because they are the oldest research method to be commonly applied in historic garden management research and are a necessary first step in conservation management planning. Biological field surveys testify to the natural heritage component of historic gardens and their importance to biodiversity. Discussions are important in establishing deontology and key terms. Survey questionnaires show interest in understanding the human element of historic gardens. Visitor surveys and interviews analyze visitor demographics, behavior and satisfaction; owner/manager surveys investigate the motives and struggles of those dedicated to such an exhausting and generally unprofitable activity. No surveys are conducted on the gardeners themselves, although various authors lament that the lack of skilled plantsmen is a serious problem. DNA analysis is applied to identify and date the origin of monumental trees and understand the suitability of necessary replacements. Policy analysis takes a critical look at the political systems governing historic garden management, paying particular attention to its history, flaws and consequences. Reviews collect all of the approaches within a given topic, in this case, economic analysis and garden tourism, to analyze trends and gaps in research. Hydraulic modeling investigates water run-off through computer modeling. Performance indicator analysis evaluates labor efficiency. Geologic surveys use soil profile sampling to better understand a site (in this case, its garden history). 
Table 4. Policy documents and institutions ranked by references.

\begin{tabular}{|c|c|c|c|}
\hline Policy Document & Year & Institution & Publications \\
\hline $\begin{array}{l}\text { National planning and conservation law } \\
\qquad(\text { no. }=13)\end{array}$ & Various & Various & $\begin{array}{c}\text { Alves et al., } 2019 \text { [33] (Portugal); } \\
\text { Askwith, } 1999 \text { [16] (UK); } \\
\text { Brine and Feather, 2010 [22] (UK); } \\
\text { Burmil, 2000 [71] (Israel); } \\
\text { Ciaffi et al., } 2018 \text { (Italy) [45]; } \\
\text { Gao and Dietze-Schirdewahn, 2018 [10] (Norway); } \\
\text { Ionescu, Illiescu and Dumitrascu, } 2010 \text { [72] (Romania); } \\
\text { Krosigk, } 1987 \text { [63] (Germany); } \\
\text { Kümmerling and Müller, } 2012 \text { [56] (Germany); } \\
\text { Mahdizadeh and Rajendran, } 2018 \text { [65] (Iran); } \\
\text { Maurer, Peschel and Schmitz, } 2000 \text { [55] (Germany); } \\
\text { Pérez-Urrestarazu et al., 2018 [43] (Spain); } \\
\text { Thorne, 2014 [42] (UK); }\end{array}$ \\
\hline $\begin{array}{l}\text { Florence Charter } \\
\quad(\text { no. }=11)\end{array}$ & 1981 & $\begin{array}{l}\text { ICOMOS- the International Federation of } \\
\text { Landscape Architects } \\
\text { (IFLA) }\end{array}$ & $\begin{array}{c}\text { Burmil, } 2000 \text { [71]; } \\
\text { de Oliveira Paiva, de Brita Sousa and Carcaud, } 2020 \text { [41]; } \\
\text { Gullino, Devecchi and Larcher, } 2020 \text { [59]; } \\
\text { Hansen, Thomsen and Rasmussen, } 2014 \text { [50]; } \\
\text { Ionescu, Iliescu, and Dumitrascu, 2010 [72]; } \\
\text { Luz, Paiva and Alves, } 2017 \text { [39]; } \\
\text { Mahdizadeh and Rajendran, } 2018 \text { [65]; } \\
\text { Mallinverni, Chiappini and Pierdicca, 2019 [44]; } \\
\text { Obad Šćitaroci et al., } 2019 \text { [35]; } \\
\text { Pérez-Urrestarazu et al., } 2018 \text { [43]; } \\
\text { Silva and Carvalho, } 2019 \text { [34]; }\end{array}$ \\
\hline $\begin{array}{l}\text { World Heritage Convention } \\
\qquad(\text { no. }=10)\end{array}$ & 1972 & UNESCO & $\begin{array}{c}\text { Askwith, } 1999 \text { [16]; } \\
\text { Cappelletti, } 2006 \text { [58]; } \\
\text { Cazzani, Zerbi and Brumana, 2019 [12]; } \\
\text { de Oliveira Paiva, de Brito Sousa and Carcaud, } 2020 \text { [41]; } \\
\text { Mahdizadeh and Rajendran, } 2018 \text { [65]; } \\
\text { Maurer, Peschel and Schmitz, } 2000 \text { [55]; } \\
\text { Obad Šćitaroci et al., 2019 [35]; } \\
\text { Pérez-Urrestarazu et al., 2018 [43]; } \\
\text { Prigoniero et al., 2020 [54]; } \\
\text { Todt, Herder and Dabija, } 2008 \text { [37]; }\end{array}$ \\
\hline
\end{tabular}


Table 4. Cont

\begin{tabular}{|c|c|c|c|}
\hline Policy Document & Year & Institution & Publications \\
\hline $\begin{array}{l}\text { Red List of Threatened Species } \\
\text { (no. }=4)\end{array}$ & $1964-^{*}$ & $\begin{array}{l}\text { International Union for Conservation of } \\
\text { Nature } \\
\text { (IUCN) }\end{array}$ & $\begin{array}{l}\text { Kowarik and Wohlgemuth, } 2006 \text { [49]; } \\
\text { Kümmerling and Müller, } 2012 \text { [56]; } \\
\text { Prigioniero et al., } 2020 \text { [54]; } \\
\text { Rostami et al., 2015 [36]; }\end{array}$ \\
\hline $\begin{array}{l}\text { European Landscape Convention } \\
\text { (no. = 3) }\end{array}$ & 2000 & Council of Europe & $\begin{array}{c}\text { Gullino, Devecchi and Larcher } 2020 \text { [59]; } \\
\text { Phillips, } 2014 \text { [75]; } \\
\text { Rostami et al., } 2015 \text { [36]; }\end{array}$ \\
\hline $\begin{array}{l}\text { Venice Charter } \\
\quad(\text { no. }=3)\end{array}$ & 1964 & ICOMOS & $\begin{array}{c}\text { Burmil, } 2000 \text { [71]; } \\
\text { Mahdizadeh and Rajendran, } 2018 \text { [65]; } \\
\text { Todt, Herder and Dabija, } 2008 \text { [37]; }\end{array}$ \\
\hline $\begin{array}{l}\text { World Heritage Convention Operational } \\
\text { Guidelines } \\
\text { (no. }=2)\end{array}$ & $1977-*$ & UNESCO & $\begin{array}{l}\text { Cazzani, Zerbi and Brumana, } 2019 \text { [12]; } \\
\text { Obad Šćitaroci et al., } 2019 \text { [35]; }\end{array}$ \\
\hline $\begin{array}{l}\text { Stockholm Conference on the Human } \\
\text { Environment (CHE) }\end{array}$ & 1972 & UN & Mahdizadeh and Rajendran, 2018 [65]; \\
\hline Burra Charter & $1979-*$ & Australia/ICOMOS & Gao and Dietze-Schirdewahn, 2018 [10]; \\
\hline Brundtland report & 1987 & $\begin{array}{l}\text { World Commission on Environment and } \\
\text { Development } \\
\text { (WCED) }\end{array}$ & Mahdizadeh and Rajendran, 2018 [65]; \\
\hline Guide to Recording Historic Buildings & 1990 & ICOMOS/UK & Counsell, 2001[23]; \\
\hline Agenda 21 & 1992 & UN & Mahdizadeh and Rajendran, 2018 [65]; \\
\hline Habitat Directive & 1992 & European Commission & Kümmerling and Müller, 2012 [56]; \\
\hline Rio Convention & 1992 & UN & Gratani, 2006 [40]; \\
\hline $\begin{array}{c}\text { The Secretary of the Interior's standards for } \\
\text { the treatment of historic properties: with } \\
\text { guidelines for the treatment of cultural } \\
\text { landscapes }\end{array}$ & 1996 & USA Department of the Interior & Halbrooks, 2005 [74]; \\
\hline $\begin{array}{l}\text { World Commission on Culture and } \\
\text { Development (WCCD, 1996) }\end{array}$ & 1996 & WCCD & Mahdizadeh and Rajendran, 2018 [65]; \\
\hline Eurogard & 1997 & $\begin{array}{c}\text { Managing Historic Gardens Working Group } \\
\text { Report }\end{array}$ & Cappelletti, 2006 [58]; \\
\hline International Cultural Tourism Charter & 1999 & ICOMOS & Todt, Herder and Dabija, 2008 [37]; \\
\hline
\end{tabular}


Table 4. Cont

\begin{tabular}{|c|c|c|c|}
\hline Policy Document & Year & Institution & Publications \\
\hline European Botanic Gardens Consortium & 2000 & $\begin{array}{c}\text { Action Plan for Botanic Gardens in the } \\
\text { European Union }\end{array}$ & Gratani, 2006 [40]; \\
\hline Faro Convention & 2005 & Council of Europe & Gao and Dietze-Schirdewahn, 2018 [10]; \\
\hline Millennium Ecosystem Assessment & 2005 & UN & Mahdizadeh and Rajendran, 2018 [65]; \\
\hline Conservation Principles & 2008 & English Heritage & Gao and Dietze-Schirdewahn, 2018 [10]; \\
\hline Carta de Juiz de Fora & 2010 & $\begin{array}{c}\text { Brazil/ } \\
\text { Instituto do Patrimônio Histórico e Artístico } \\
\text { Nacional (IPHAN) }\end{array}$ & Luz, Paiva and Alves, 2017 [39]; \\
\hline $\begin{array}{c}\text { Historic Urban Landscape } \\
\text { Recommendations }\end{array}$ & 2011 & UNESCO & Wahurwagh and Dongre, 2015 [70]; \\
\hline People-Centered Approaches & 2015 & $\begin{array}{l}\text { International Centre for the Study of the } \\
\text { Preservation and Restoration of Cultural } \\
\text { Property (ICCROM) }\end{array}$ & Gao and Dietze-Schirdewahn, 2018 [10]. \\
\hline
\end{tabular}

* A hyphen (-) indicates a living document that continues to be periodically revised. The year before the hyphen indicates the year of the first edition of that document. 
Table 5. Study methods ranked by number of publications.

\begin{tabular}{|c|c|c|}
\hline Study Method & No. Studies & References \\
\hline Case study & 20 & $\begin{array}{c}\text { Abdel-Rahman, 2016 [68]; } \\
\text { Alves et al., } 2019 \text { [33]; } \\
\text { Bergande and Markstein, 2013 [62]; } \\
\text { Burmil, 2000 [71]; } \\
\text { Cappelletti, } 2006 \text { [58]; } \\
\text { Cazzani, Zerbi and Brumana, 2019 [12]; } \\
\text { Counsell, } 2001 \text { [23]; } \\
\text { Flinck, 2016 [73]; } \\
\text { Gratani, } 2006 \text { [40]; } \\
\text { Halbrooks, } 2005 \text { [74]; } \\
\text { Gullino, Devechi and Larcher, } 2020 \text { [59]; } \\
\text { Ionescu, Iliescu and Dumitrascu, 2010 [72]; } \\
\text { Khalilnezhad, } 2017 \text { [64]; } \\
\text { Luz, Paiva and Alves, 2018 [39]; } \\
\text { Mahmood and Nasim, 2012 [66]; } \\
\text { Malinverni, Chiappini and Pierdicca, 2019 [44]; } \\
\text { Mang, 2013 [67]; } \\
\text { Obad Šćitaroci et al., 2019 [35]; } \\
\text { Tisi, 2006 [61]; } \\
\text { Wahurwagh and Dongre, 2015 [70]; }\end{array}$ \\
\hline Biological field survey & 8 & $\begin{array}{c}\text { Arteaga et al., } 2020 \text { [53]; } \\
\text { Gullino, Larcher and Devecchi, } 2010 \text { [59]; } \\
\text { Kowarik and Wohlgemuth, } 2006 \text { [49]; } \\
\text { Kümmerling and Müller, } 2012 \text { [56]; } \\
\text { Maurer, Peschel and Schmitz, } 2000 \text { [55]; } \\
\text { Nascimbene and Salvadori, } 2008 \text { [60]; } \\
\text { Oishi, 2020 [51]; } \\
\text { Prigioniero et al., 2020 [54]; }\end{array}$ \\
\hline Discussion & 7 & $\begin{array}{c}\text { Albericci, } 2006 \text { [18]; } \\
\text { Boisset, } 1980 \text { [19]; } \\
\text { Krosigk, } 1987 \text { [63]; } \\
\text { Sales, } 2000 \text { [21]; } \\
\text { Thoday, } 2014 \text { [20]; } \\
\text { Thorne, } 2014 \text { [42]; } \\
\text { Todt, Herder and Dabija, } 2008 \text { [37]; }\end{array}$ \\
\hline Survey questionnaire/interview & 6 & $\begin{array}{l}\text { Brine and Feather, } 2010 \text { [22]; } \\
\text { Gao and Dietze-Schirdewahn, 2018 [10]; } \\
\text { Meda and Rinaldi, } 2006 \text { [17]; } \\
\text { Rostami et al., } 2015 \text { [36]; } \\
\text { Saeed et al., 2017 [38]; } \\
\text { Silva and Carvalho, } 2020 \text { [34]; }\end{array}$ \\
\hline DNA mapping & 2 & $\begin{array}{c}\text { Ciaffi, } 2018 \text { [45]; } \\
\text { Hansen, Thomsen and Rasmussen, } 2014 \text { [50]; }\end{array}$ \\
\hline Policy analysis & 2 & $\begin{array}{l}\text { Mahdizadeh and Rajendran, } 2018 \text { [65]; } \\
\text { Phillips, } 2014 \text { [75]; }\end{array}$ \\
\hline Review of economic analysis & 1 & Askwith, 1999 [16]; \\
\hline Review of tourism studies & 1 & de Oliveira Paiva, de Brito Sousa and Carcaud, 2020 [41]; \\
\hline Hydraulic modeling & 1 & Cavagnero and Revelli, 2009 [57]; \\
\hline Performance indicators & 1 & Pérez-Urrestarazu et al., 2018 [43]; \\
\hline Geologic field survey & 1 & Visacc, 2005 [69] \\
\hline
\end{tabular}

Askwith's review of economic analysis studies [16] deserves special mention here because it presents important research methods from the fields of Resource Economics and Appraisal that cannot be found elsewhere in the reviewed literature. Askwith herself notes a lack of economic studies on 
historic gardens. She laments that most of the publications available are flawed or inconsistent grey literature. The few academic studies in her review that are indexed in Scopus present some economic appraisal techniques to evaluate the monetary value of non-market goods, specifically: measurement of the influence of trees on residential property values through before and after comparisons [76]; appraisal of the recreational benefits provided by botanical gardens and national parks through the travel-cost method [77,78]; comparison of visitor number trends, admission prices and on-site spending in privately owned heritage estates [79]; appraisal of the value of urban amenities with a hedonic-pricing model [80]; comparison of use and non-use value for a heritage site estimated through contingent valuation (visitor's willingness to pay for entry or to pay for preservation without entry) to revenue from admission charges or to average visitor donation $[81,82]$. As mentioned above in Section 3.1, the economic appraisal of the costs and benefits of historic gardens is not only important for improving the fragile economic sustainability of these public assets but also necessary to hold institutions accountable when they do not properly care for or provide these assets. Considering the importance of these aspects, it is surprising that this 1999 study was not followed by other economic assessment studies explicitly dedicated to historic gardens.

De Oliveira Paiva, de Brito Sousa, and Carcaud's (2020) review of tourism studies includes a wide range of work exploring the subject of garden tourism. The studies in their review that are indexed in Scopus provide several examples of garden tourism methodologies that can be fruitfully applied to historic gardens, including: on-site and frontier survey questionnaires and interviews to investigate garden owners [2], garden [83] or heritage [84,85] visitors and their experience; trip advisor review content analysis compared to the declared management objectives of botanical gardens [86]; modeling of the tourist attraction system [87]; historical reconstruction through site visits, interviews, bibliographic and iconographic research [88]; discussions of pertinent themes such as the geography of gardens [89,90], the history of Iranian ornamental horticulture and historic gardens [91,92], and the evolving role of botanical gardens [93-95]. Some of these research instruments are used in other studies in this historic garden management review, while some are new.

\subsection{Bias Scores}

Bias scores from 0-2 are attributed to each study based on the following system. One point is awarded if policy documents are found in a study in response to research question six; one point is awarded if a study is based on empirical data in response to research question seven. Classification by bias score is shown in Table 6. Obviously, such minimal criteria result in a wide range of studies within each class. However, this seems to be the only appropriate way to not favor or penalize one academic discipline over another. Some of these studies certainly do not intend to be free of bias, and it should be noted that this score does not reflect on the intellectual quality of the work. Furthermore, it should also be specified that any bias in question specifically regards a publication's treatment of historic gardens, without passing judgment on other items under investigation by the authors.

Regarding the distribution of bias scores: 27 publications are attributed 2 points, 19 are attributed 1 point, and 4 are attributed 0 . These latter are written as essays, with no intention of being unbiased. The middle group contains a wide variety of publications, some of which are perfectly valid scientific studies but do not cite historic garden policy. In the context of this review, it is felt that heritage is inherently political. Thus, the highest-rated literature makes a point of basing their use of key terminology and procedure on specific policy documents.

\subsection{Garden Use}

In response to research question 10, the studies discussed in this section are divided into categories regarding general gardens, public gardens, tourist gardens and private gardens (Table 7). This division of the studies by garden use is adapted from Askwith (1999) [16] and is further motivated by the repeated relevance given to use and access in other reviewed studies. "General" captures those publications that do not fit into the other more specific categories. "public" regards gardens that are 
pure public goods (they are non-rival and non-exclusive). Although they generate many benefits, these are mainly external to the market. Public gardens pay for their upkeep through public funding, which may constrict their hiring and contracting abilities. The third category, "tourist," regards gardens that directly generate revenue from entry tickets and complementary services (gift shops, cafés, special events). However, they also generate external benefits and can be financially supported by public funding, tax exemptions, private donations and sponsorship. They may be privately owned, with the use and care of the property relegated by national, regional and municipal regulations. Compliance can impose additional costs on owners; however, listed status can increase property values, allow owners to benefit from tax exemptions or grants and attract more visitors. These gardens may also be publicly owned, usually by national or regional rather than municipal entities. In Europe, there is an increasing trend of publicly owned heritage sites being managed by private enterprises [96]. In this case, fixed costs may be covered by public expenditure, while variable costs are covered by the revenue generated through visitor services [96]. The fourth category, "private", regards historic gardens that are primarily used for their owner's own enjoyment and are generally not open to the public. However, they still produce significant environmental, social and economic benefits for both the owner and the wider community.

Table 8 compares the four historic garden use categories according to the other research criteria. The composition by category is also given for the entire corpus of the literature review. The distinguishing characteristics of each group are discussed in the following four subsections.

\subsubsection{General Gardens}

$13 / 50$ of the publications in this review are general, regarding all types of historic gardens. This category shows the strongest tendency towards a supply orientation and focuses on the strategic management phase. It also has the broadest geographic scale, the fewest studies with explicit sites, the fewest empirically-based studies and the lowest average bias score (1.4). In fact, six of the nine theoretical studies come from the general garden category. The main research method employed is discussion.

Authors such as Boisset [19], Sales [21], Thoday [20], and Thorne [42] all discuss the best practices of historic garden management and seem to address their work towards professionals rather than academics. All but Thorne (who mentions planning and conservation laws) receive a 0 because they neither cite policy documents nor base their study on empirical investigation. Indeed, their aim is not to be unbiased, but instead to transmit their experience and views efficiently to the harried workers keeping historic gardens afloat. Krosigk [63], Phillips [75], and Mahdizadeh and Rajendran [65] all focus on the evolution of the policy governing historic garden conservation. The latter work is particularly interesting because the authors address a politically turbulent area (Iran), where gardens are conserved or destroyed according to reigning political ideologies. Indeed, this work demonstrates that one must not take public policy for granted, but critically evaluate the efficiency and even the motives of political institutions. Public choice theory, i.e., the economic study of public policy that admits that government officials and bureaucrats act according to "personal objectives in collective decision making, just as they do in the market" [97], has been used to understand heritage preservation policy $[96,98]$ and would doubtless prove insightful if applied to historic garden policy as well. Askwith [16] offers an overview of the economic impact of historic gardens in the United Kingdom through a literature review. Vissac [69], Kowarik and Wohlgemuth [49] and Gullino, Devecchi and Larcher [59] all use historic gardens as living laboratories where historical research is combined with geologic or biologic site analysis to investigate the evolving landscape. Khalilnezhad [64] and Obad Šćitaroci et al. [35] seek to identify architectural-historic garden typologies and renewal models.

Seen together, it is evident that the studies in the general gardens category most explicitly address the nature and value of historic gardens, taking a panoramic perspective. Many of these studies are in the form of essays or discussions or best practice overviews for professionals. The most informative studies in this category see historic gardens as embedded in a larger social, economic and environmental 
system and use precise empirical methods to measure that embeddedness: policy analysis for social systems, market analysis and valuation for economic systems, site surveys for environmental systems.

Table 6. Bias ratings for reviewed publications.

\begin{tabular}{|c|c|c|}
\hline Bias Score & No. Articles & Reference \\
\hline 0 & 4 & $\begin{array}{l}\text { Boisset, } 1980 \text { [19]; } \\
\text { Sales, } 2000 \text { [21]; } \\
\text { Albericci, } 2006 \text { [18]; } \\
\text { Thoday, } 2014 \text { [20]; }\end{array}$ \\
\hline 1 & 19 & $\begin{array}{c}\text { Abdel-Rahman, } 2016 \text { [68]; } \\
\text { Arteaga et al., 2020 [53]; } \\
\text { Bergande and Markstein, 2013 [62]; } \\
\text { Flinck, 2016 [73]; } \\
\text { Gullino, Larcher and Devecchi, } 2010 \text { [52]; } \\
\text { Ionescu, Iliescu and Dumitrascu, } 2010 \text { [72]; } \\
\text { Khalilnezhad, } 2017 \text { [64]; } \\
\text { Krosigk, 1987 [63]; } \\
\text { Mahmood and Nasim, 2012 [66]; } \\
\text { Maurer, Peschel and Schmitz, } 2000 \text { [55]; } \\
\text { Meda and Rinaldi, 2006 [17]; } \\
\text { Nascimbene and Salvadori, 2008 [60]; } \\
\text { Oishi, 2019 [51]; } \\
\text { Phillips, } 2014 \text { [75]; } \\
\text { Saeed et al., 2017 [38]; } \\
\text { Thorne, 2014 [42]; } \\
\text { Tisi, 2006 [61]; } \\
\text { Vissac, 2005 [69]; }\end{array}$ \\
\hline 2 & 27 & $\begin{array}{c}\text { Alves et al., } 2019 \text { [33]; } \\
\text { Askwith, 1999 [16]; } \\
\text { Brine and Feather, 2010 [22]; } \\
\text { Burmil, 2000 [71]; } \\
\text { Cappelletti, } 2006 \text { [58]; } \\
\text { Cavagnero and Revelli, 2009 [57]; } \\
\text { Cazzani, Zerbi and Brumana 2019 [12]; } \\
\text { Ciaffi et al., 2018 [45]; } \\
\text { Counsell, } 2001 \text { [23]; } \\
\text { 2020 [41]; } \\
\text { de Oliveira Paiva, de Brito Sousa and Carcaud, } \\
\text { Gao and Dietze-Schirdewahn, } 2018 \text { [10]; } \\
\text { Gratani, 2006 [40]; } \\
\text { Gullino, Devecchi and Larcher, 2020 [59]; } \\
\text { Halbrooks, 2005 [74]; } \\
\text { Hansen, Thomsen and Rasmussen, 2014 [50]; } \\
\text { Kowarik and Wohlgemuth, 2006 [49]; } \\
\text { Kümmerling and Müller, 2012 [56]; } \\
\text { Luz, Paiva, and Alves, 2017 [39]; } \\
\text { Malinverni, Chiappini and Pierdicca, 2019 [44]; } \\
\text { Mahdizadeh and Rajendran, 2019 [65]; } \\
\text { Mang, 2013 [67]; } \\
\text { Obad Šćitaroci et al., 2019 [35]; } \\
\text { Pérez-Urrestarazu et al., 2018 [43]; } \\
\text { Prigioniero et al., 2020 [54]; } \\
\text { Rostami et al., 2012 [36]; } \\
\text { Silva and Carvalho, 2020 [34]; } \\
\text { Wahurwagh and Dongre, 2006 [70] }\end{array}$ \\
\hline
\end{tabular}


Table 7. Historic garden coverage by use (general, public, tourist, private).

\begin{tabular}{|c|c|c|}
\hline Garden Use & No. Studies & Reference Information \\
\hline General & 13 & $\begin{array}{c}\text { Askwith, } 1999 \text { [16]; } \\
\text { Boisset, } 1980 \text { [19]; } \\
\text { Gullino, Devecchi and Larcher, 2020 [59] } \\
\text { Khalilnezhad, } 2017 \text { [64]; } \\
\text { Kowarik and Wohlgemuth, 2006 [49]; } \\
\text { Krosigk, 1987 [63]; } \\
\text { Mahdizadeh and Rajendran, } 2019 \text { [65]; } \\
\text { Obad Šćitaroci et al., 2019 [35]; } \\
\text { Phillips, } 2014 \text { [75]; } \\
\text { Sales, } 2000 \text { [21]; } \\
\text { Thoday, } 2014 \text { [20]; } \\
\text { Thorne, } 2014 \text { [42]; } \\
\text { Vissac, } 2005 \text { [69]; }\end{array}$ \\
\hline Public & 7 & $\begin{array}{c}\text { Abdel-Rahman, } 2016 \text { [68]; } \\
\text { Cazzani, Zerbi and Brumana, 2019 [12]; } \\
\text { Ionescu, Iliescu and Dumitrascu, } 2010 \text { [72]; } \\
\text { Luz, Paiva and Alves, } 2017 \text { [39]; } \\
\text { Maurer, Peschel and Schmitz, 2000 [55]; } \\
\text { Rostami et al., } 2015 \text { [36]; } \\
\text { Wahurwagh and Dongre, } 2015 \text { [70]; }\end{array}$ \\
\hline Tourist & 27 & $\begin{array}{c}\text { Albericci, } 2006 \text { [18]; } \\
\text { Alves et al., 2019 [33]; } \\
\text { Arteaga et al., 2020 [53]; } \\
\text { Bergande and Markstein, 2013 [62]; } \\
\text { Brine and Feather, 2010 [22]; } \\
\text { Burmil, 2000 [71]; } \\
\text { Cappelletti, } 2006 \text { [58]; } \\
\text { Cavagnero and Revelli, 2009 [57]; } \\
\text { Ciaffi et al., } 2018 \text { [45]; } \\
\text { Counsell, } 2001 \text { [23]; } \\
\text { 2020 [41]; } \\
\text { de Oliveira Paiva, de Brito Sousa and Carcaud, } \\
\text { Gratani, 2006 [40]; } \\
\text { Halbrooks, } 2005 \text { [74]; } \\
\text { Hansen, Thomsen and Rasmussen, 2014 [50]; } \\
\text { Kümmerling and Müller, 2012 [56]; } \\
\text { Mahmood and Nasim, 2012 [66]; } \\
\text { Malinverni, Chiappini and Pierdicca, 2019 [44]; } \\
\text { Mang, 2013 [67]; } \\
\text { Meda and Rinaldi, 2006 [17]; } \\
\text { Nascimbene and Salvadori, 2008 [60]; } \\
\text { Oishi, 2019 [51]; } \\
\text { Pérez-Urrestarazu et al., 2018 [43]; } \\
\text { Prigioniero et al., 2020 [54]; } \\
\text { Saeed et al., 2017 [38]; } \\
\text { Silva and Carvalho, 2019 [34]; } \\
\text { Tisi, 2006 [61]; } \\
\text { Todt, Herder and Dabija, 2008 [37]; }\end{array}$ \\
\hline Private & 3 & $\begin{array}{l}\text { Flinck, } 2016 \text { [73]; } \\
\text { Gao and Dietze-Schirdewahn, } 2018 \text { [10]; } \\
\text { Gullino, Larcher and Devecchi, } 2010 \text { [59] }\end{array}$ \\
\hline
\end{tabular}


Table 8. Literature characteristics by use (general, public, tourist, private) ${ }^{*}{ }^{\dagger}$.

\begin{tabular}{|c|c|c|c|c|c|}
\hline Use & General & Public & Tourist & Private & Total Review \\
\hline$\%$ Total & $26.00 \%$ & $14.00 \%$ & $54.00 \%$ & $6.00 \%$ & $100.00 \%$ \\
\hline $\begin{array}{l}\text { Supply/ } \\
\text { demand }\end{array}$ & $\begin{array}{l}84.6 \% \text { sup. } \\
0.0 \% \text { dem. } \\
15.4 \% \text { both }\end{array}$ & $\begin{array}{l}71.4 \% \text { sup. } \\
14.3 \% \text { dem. } \\
14.3 \% \text { both }\end{array}$ & $\begin{array}{l}81.5 \% \text { sup. } \\
11.1 \% \text { dem. } \\
7.4 \% \text { both }\end{array}$ & $\begin{array}{c}100.0 \% \text { sup. } \\
0.0 \% \text { dem. } \\
0.0 \% \text { both }\end{array}$ & $\begin{array}{l}82.0 \% \text { sup. } \\
8.0 \% \text { dem. } \\
10.0 \% \text { both }\end{array}$ \\
\hline Management phase & $\begin{array}{c}61.5 \% \text { strat. } \\
15.4 \% \text { oper. } \\
7.7 \% \text { ass. } \\
15.4 \% \text { combo }\end{array}$ & $\begin{array}{c}57.1 \% \text { strat. } \\
0.0 \% \text { oper. } \\
42.9 \% \text { ass. } \\
0.0 \% \text { combo }\end{array}$ & $\begin{array}{c}33.3 \% \text { strat. } \\
3.7 \% \text { oper. } \\
55.6 \% \text { ass. } \\
7.4 \% \text { combo }\end{array}$ & $\begin{array}{c}33.3 \% \text { strat. } \\
0.0 \% \text { oper. } \\
66.7 \% \text { ass. } \\
0.0 \% \text { combo }\end{array}$ & $\begin{array}{c}44.0 \% \text { strat. } \\
6.0 \% \text { oper. } \\
42.0 \% \text { ass. } \\
8.0 \% \text { combo }\end{array}$ \\
\hline Sustainability & $\begin{array}{l}69.2 \% \text { soc. } \\
15.4 \% \text { econ. } \\
15.4 \% \text { env. } \\
0.0 \% \text { combo }\end{array}$ & $\begin{array}{l}71.4 \% \text { soc. } \\
0.0 \% \text { econ. } \\
14.3 \% \text { env. } \\
14.3 \% \text { combo }\end{array}$ & $\begin{array}{l}48.1 \% \text { soc. } \\
11.1 \% \text { econ. } \\
25.9 \% \text { env. } \\
14.8 \% \text { combo }\end{array}$ & $\begin{array}{c}66.7 \% \text { soc. } \\
0.0 \% \text { econ. } \\
0.0 \% \text { env. } \\
33.3 \% \text { combo }\end{array}$ & $\begin{array}{c}58.0 \% \text { soc. } \\
10.0 \% \text { econ. } \\
20.0 \% \text { env. } \\
12.0 \% \text { combo }\end{array}$ \\
\hline Geographic scale & $\begin{array}{c}7.7 \% \text { loc. } \\
15.4 \% \text { reg. } \\
53.8 \% \text { nat. } \\
23.1 \% \text { inter. }\end{array}$ & $\begin{array}{l}57.1 \% \text { loc. } \\
14.3 \% \text { reg. } \\
28.6 \% \text { nat. } \\
0.0 \% \text { inter. }\end{array}$ & $\begin{array}{c}59.3 \% \text { loc. } \\
7.4 \% \text { reg. } \\
22.2 \% \text { nat. } \\
11.1 \% \text { inter. }\end{array}$ & $\begin{array}{l}33.3 \% \text { loc. } \\
33.3 \% \text { reg. } \\
33.3 \% \text { nat. } \\
0.0 \% \text { inter. }\end{array}$ & $\begin{array}{l}44.0 \% \text { loc. } \\
12.0 \% \text { reg. } \\
32.0 \% \text { nat. } \\
12.0 \% \text { inter. }\end{array}$ \\
\hline$\%$ Explicit sites & $\begin{array}{l}38.5 \% \text { yes } \\
61.5 \% \text { no }\end{array}$ & $\begin{array}{l}86.0 \% \text { yes } \\
14.0 \% \text { no }\end{array}$ & $\begin{array}{l}88.9 \% \text { yes } \\
11.1 \% \text { no }\end{array}$ & $\begin{array}{c}100.0 \% \text { yes } \\
0.0 \% \text { no }\end{array}$ & $\begin{array}{l}76.0 \% \text { yes } \\
24.0 \% \text { no }\end{array}$ \\
\hline $\begin{array}{c}\text { \% Explicit policy } \\
\text { references }\end{array}$ & $\begin{array}{l}61.5 \% \text { yes } \\
38.5 \% \text { no }\end{array}$ & $\begin{array}{c}85.7 \% \text { yes } \\
14.3 \% \text { no }\end{array}$ & $\begin{array}{l}66.7 \% \text { yes } \\
33.3 \% \text { no }\end{array}$ & $\begin{array}{l}33.3 \% \text { yes } \\
66.7 \% \text { no }\end{array}$ & $\begin{array}{l}66.0 \% \text { yes } \\
34.0 \% \text { no }\end{array}$ \\
\hline $\begin{array}{l}\text { Empirical/ } \\
\text { theoretical }\end{array}$ & $\begin{array}{l}53.8 \% \text { emp. } \\
46.2 \% \text { theo. }\end{array}$ & $\begin{array}{c}100.0 \% \text { emp. } \\
0.0 \% \text { theo. }\end{array}$ & $\begin{array}{l}92.6 \% \text { emp. } \\
7.4 \% \text { theo. }\end{array}$ & $\begin{array}{c}100.0 \% \text { emp. } \\
0.0 \% \text { theo. }\end{array}$ & $\begin{array}{l}84.0 \% \text { emp. } \\
16.0 \% \text { theo. }\end{array}$ \\
\hline Method & $\begin{array}{l}\text { Discussion } \\
(38.5 \%)\end{array}$ & $\begin{array}{l}\text { Case study } \\
\quad(71.4 \%)\end{array}$ & $\begin{array}{l}\text { Case study } \\
(40.7 \%)\end{array}$ & $\begin{array}{c}\text { Biological } \\
\text { field survey } \\
(33.3 \%), \\
\text { Case study } \\
(33.3 \%), \\
\text { Survey } \\
\text { questionnaire } \\
(33.3 \%)\end{array}$ & $\begin{array}{l}\text { Case study } \\
\quad(40.0 \%)\end{array}$ \\
\hline Bias & $\begin{array}{l}23.1 \%=0 \\
38.5 \%=1 \\
38.5 \%=2\end{array}$ & $\begin{array}{c}0.0 \%=0 \\
42.9 \%=1 \\
57.1 \%=2\end{array}$ & $\begin{array}{c}3.7 \%=0 \\
33.3 \%=1 \\
63.0 \%=2\end{array}$ & $\begin{array}{c}0.0 \%=0 \\
33.3 \%=1 \\
66.7 \%=2\end{array}$ & $\begin{array}{c}8.0 \%=0 \\
38.0 \%=1 \\
54.0 \%=2\end{array}$ \\
\hline
\end{tabular}

${ }^{*}$ Abbreviations: sup. (supply); dem. (demand); strat. (strategic); oper. (operational); ass. (assessment); soc. (social); econ. (economic); env. (environmental); loc. (local); reg. (regional); nat. (national); inter. (international); emp. (empirical); theo. (theoretical). ${ }^{\dagger}$ Percentages are rounded off to the nearest decimal, and thus sometimes do not total up to exactly $100 \%$.

\subsubsection{Public Gardens}

With only 7/50 examples, the public historic garden category is quite under-represented. This is surprising, considering how important historic green spaces in urban areas are, with many coming from the internationally spanning 19th-century Parks Movement. Furthermore, policy douments such as the UN Sustainability Goals [11] and the UNESCO's Historic Urban Landscape Recommendations [99] puts great emphasis on the importance of both green spaces and cultural heritage in the city. One can only surmise that public spaces are the most difficult to obtain visitor and financial information for and perhaps the least glamorous for researchers. Nonetheless, all studies in this category are empiric investigations, with the case study method predominating. No study in the group has a bias score of 0 , and the category average is 1.49 .

Of all the use categories, public gardens show the largest percentage (14.3\%) dedicated to demand (although the small size of the category makes all of the percentages for this category indicative and not statistically robust). Demand analysis should be an important part of public historic garden 
management because they are paid for through taxation with the intention of increasing public welfare. Rostami et al. [36] analyze demand by surveying visitors in four Persian gardens and, to a limited extent by Luz, Paiva and Alves [39], by interviewing visitors as part of a site evaluation in Brazil. Public garden studies show the most interest in strategic management (57.1\%), followed by assessment $(42.9 \%)$. Of all of the categories, they show the highest interest in social sustainability (71.4\%). An important characteristic defining public garden studies relate to their public good quality; they should investigate specific politically defined territories so that results reflect on responsible governing institutions and their allocation of resources and efficiency. Cazzani, Zerbi and Brumana [12] point out that many public historic gardens were originally designed as private residences and describe how this change of management affects garden conservation. All but two studies in this category investigate a clearly delimited geo-political area: Maurer, Peschel and Schmitz [55] survey different land-use types in the capital city of Berlin, Germany; Ionescu, Iliescu -and Dumitrascu [72] catalog historic garden sites in the capital city of Bucharest, Romania; Rostami et al. [36] investigate representative historic gardens in Iran; Wahurwagh and Dongre [70] evaluate the cultural landscape conservation of the metropolitan area of Burhanpur, India; Abdel-Rahman catalogs overlooked historic parks in the capital city of Cairo, Egypt [68].

The geographic diversity of these studies is also noteworthy, with four coming from outside Europe $[36,39,68,70]$. The availability of public parks is an important indicator of wellbeing. Interest and demand for them may be correlated with development trends in these areas, including rising standards of living, education, and leisure time. Because public gardens are government-managed, policy is particularly important for this category. In fact, all but one of the studies cites specific policy documents. These include national planning and conservation law; the World Heritage Convention; the World Heritage Convention Operational guidelines; the Florence Charter, the Red List of Threatened Species; the European Landscape Convention; the Historic Urban Landscape Recommendations; and the Carta de Juiz de Fora (the Brazilian Historic Garden Charter). Surprisingly, the 2017 ICOMOS-IFLA Document on Historic Urban Public Parks [100] is not mentioned. This document specifically addresses historic public gardens and should be considered in future studies.

What emerges most in the analysis of this historic garden category is the pure public good nature of public historic gardens. The most successful studies in this category evaluate governments' management of historic gardens to increase citizens' welfare. They achieve this by being situated in defined geopolitical territories, documenting the governing body in question's policy, and analyzing the community's demand and value for historic gardens.

\subsubsection{Tourist Gardens}

Classifying the gardens by use shows that the majority (27/50) of historic garden research regards tourist gardens. This is unsurprising since tourist gardens are more well known and automatically generate visitor and financial information through ticket sales. In fact, this category of garden use contains the majority of studies involving the assessment phase of management (15/27). This might imply that these gardens are particularly motivated to manage their resources efficiently because they are economic ventures (generally small to medium businesses). Furthermore, they are often accountable to national and international bodies and must also demonstrate their commitment to objectives other than profit, such as public outreach and environmental or cultural heritage conservation. This category contains all but one of this literature review's demand-oriented studies, with Todt, Herder and Dabija [37] offering a discussion of the role of monument protection in tourism; Saeed et al. [38] performing a case study of visitor satisfaction in three Moghul Gardens in Pakistan; Silva and Carvalho [34] profiling historic garden visitors in Portugal and comparing their data to similar studies performed in the United Kingdom. In addition, Gratani [40] and de Oliveira Paiva, de Brito Sousa and Carcaud [41] compare both supply and demand in the Rome Botanical Garden (Rome, Italy) and in the international garden tourism market, respectively. 
Most of these studies are interested in social sustainability, just as in all of the other user categories. However, this is the only category where this percentage is less than half (48.1\%). In the earlier years of historic garden management studies, publications regarding social sustainability in the tourist garden category appear that are interested in problems of conserving the fabric (i.e., material composition) of cultural heritage: Burmil [71] discusses conservation treatments of the Ramat Hanadiv memorial gardens in Israel; Counsell [23] inventories three European case studies using spatial information systems to store and access information; Halbrooks [74] documents the restoration of the English Garden at Stan Hywet Hall (USA); Cappelletti [58] discusses the Padua Botanic Gardens (Italy), Nascibene and Salvadori [60] investigate restorative cleaning practices of limestone statues in Venetian villas (Italy); Mahmood and Nasim [66] propose a reconstruction of a historic Persian garden in Bojnourd, Iran; Mang [67] documents the care of the Austrian Federal Gardens (Austria); Alves et al. [33] document the restoration of an 18th century bridge within the Queluz National Palace Gardens (Portugal); Malinverni, Chiappini and Pierdicca [44] use geographic information systems (GIS) to catalogue the living and non-living fabric of Villa Bounaccorsi's historic garden (Italy). More recently, social sustainability studies in the tourist garden category have begun to look beyond the physical fabric of cultural heritage and also investigate intangible social value: Tisi [61] describes educational, and public outreach activities in Trentino (Italy); Brine and Feather [22] look at the motives and struggles of heritage property owners in the UK; Saeed et al. [38] and Silva and Carvalho's [34] previously mentioned visitor studies implicitly evaluate equity by collecting demographic statistics on the visitors who access and benefit from the historic gardens in question. It is also interesting to note that three of the literature review's five economic sustainability articles are from the tourist garden category. Todt et al. [37] and de Oliveira Paiva, de Brita Sousa and Carcaud [41] examine the economic implications of historic garden tourism, and Meda and Rinaldi [17] analyze the particular funding and labor problems of Italian University Botanical Gardens.

Of all the use categories, tourist garden studies show the highest interest in environmental sustainability $(25.9 \%)$. Most of these studies are particularly interested in historic gardens' role in conserving biodiversity: Kümmerling and Müller [56] investigate the relationship between landscape design style and conservation value in a UNESCO world heritage site (Germany); Bergande and Markstein [62] discuss a preservation and management plan for the Berlin-Dahlem Botanic Garden that specifically aims to conserve biodiversity (Germany); Arteaga et al. [53] investigate arthropod diversity in historic gardens in the Azores archipelago (Portugal); Prigioniero et al. [54] investigate the conservation of biodiversity in the Giardino Inglese at the Reggio di Caserta (Italy). Other sustainability issues are addressed by Cavagnero and Revelli's article on water run-off control within the Racconigi Royal Park (Italy) using hydraulic modeling [57]; Pérez-Urrestarazu et al.'s article on water management within the Real Alcazar gardens (Spain) [43]; Oishi's article on the urban heat island's effect on traditional Japanese moss gardens [51].

Three studies are interested in the relationship between social and environmental sustainability, with Albericci [18] investigating the relationship between biodiversity conservation and public education at the Botanical Garden of Rome (Italy); Hansen, Thomson and Rasmussen [50] investigating the genetic profile of historic lime tree plantings in the Royal Danish Gardens (Denmark); Ciaffi et al. [45] investigating the conservation of historic plane trees in Villa Lante (Italy). The second two are noteworthy because they attribute a primarily social value to historic trees, rather than an environmental value.

In terms of geographic scale, this group has the highest percentage of local studies (59.3\%). This is because many of these studies either concentrate on a specific garden or a group of gardens in the same city. In fact, almost all studies $(88.9 \%)$ investigate specific sites and are based on empiric research $(92.6 \%)$. The tourism garden category follows the same distribution in policy document citation as the whole literature corpus, with $2 / 3$ explicitly citing policy and $1 / 3$ not citing policy. The main research method in this category is the case study $(40.7 \%)$, followed by the biological field survey $(18.5 \%)$ and the survey questionnaire (14.8\%). The category's average bias score is 1.5 . 
Aside from the research criteria, an unexpected trend to emerge in the tourist garden category is the appearance of several botanical gardens. Indeed, both Askwith [16], Silva and Carvalho [34] and de Oliveira Paiva, de Brita Sousa and Carcaud [41] use botanical gardens to estimate the historic garden tourism market because they keep precise visitor and financial records, are among the most marketed garden attractions and are sometimes even included as a category (with zoos) in tourism-board statistics [34]. Of course, a botanical garden is not necessarily a historic garden. Botanical Gardens Conservation International defines botanical gardens as "institutions holding documented collections of living plants for the purpose of scientific research, conservation, display and education"[101]. Tisi [61] and Gratani [40] discuss Botanical Garden educational activities, while Arteaga et al.'s study of the Faial Botanical Garden in Portugal [53] provides an example of scientific research. While new botanical gardens can be built at any time to fulfill their mission, historic botanical gardens bear a double responsibility of carrying out the aforementioned mandates while also preserving their heritage value. Cappelletti [43] and Bergande and Markstein [62] describe how management planning has tried to deal with both missions in Padova and Berlin. Albericci [18] and Meda [17] show that despite being the "best publicized gardens"[34], botanical gardens have serious problems with labor and with financial resources.

What emerges most in this category is the importance of the non-monetary mandates of these gardens. Although tourism gardens are economic businesses, their income is only a means to fulfill other goals. These mandates are determined both by the individual owner/managers and by outside stakeholders. The sustainability criterion is particularly useful in drawing out the different possible mandates of tourist historic gardens. Tourist garden studies also most clearly show social sustainability falling between two groups: studies concerned with the tangible heritage value of the gardens in question and studies concerned with the intangible benefits that motivate both visitors and owners to spend their time and money on historic gardens.

\subsubsection{Private Gardens}

Although private gardens are only represented by three studies in this review, they shed light on some interesting issues. Gullino, Larcher and Devecchi [52] illustrate their role in conserving monumental trees; Flinck [73] shows how private historic gardens create neighborhood identity and amenity value; Gao and Dietze-Schirdewahn [10] investigate how private gardens conserve intangible cultural heritage. Outside this category, both Askwith [16] and Silva and Carvalho [39] note a connection between owning a garden and garden visitation in the UK. They also note that owners of private historic gardens are more likely to participate in garden clubs and associations and in garden tourism. All three studies are supply-oriented; one is dedicated to strategic management and two are dedicated to assessment; two regard social sustainability while one looks at both social and environmental sustainability equally; the studies are evenly split between local, regional and national scales; all identify sites; two cite policy documents; all are empirically based; research methods are split between biological field survey, case study, and survey questionnaire; the average bias rating is 1.67. While not much can be surmised based on the statistics of only three studies, this category certainly shows much potential for future research. The issue of intangible cultural heritage preserved through every-day life seems the most promising aspect to emerge here.

\section{Discussion}

This review set out to collect the many different threads of multidisciplinary research investigating historic garden management in order to arrive at a comprehensive vision of the subject, evaluate its progress, and give indications for future development. With these aims, the body of interdisciplinary literature available in two leading scientific databases has been categorized according to 10 research criteria. In this last section, the larger ramifications of these findings are discussed, and gaps in the literature are identified. Particular attention is paid to the changing conceptual foundations of policy and practice and the gap between the two; the community and stakeholders as protagonists of 
historic garden management; the social, economic and environmental sustainability of historic gardens; the emergence of previously unrepresented cultures and regions; the diversifying methodologies and interdisciplinary approaches being applied in the subject. Some studies from outside of the reviewed literature are also cited in this section as suggested examples of promising empiric methods and directions.

\subsection{Changing Conceptual Frameworks in Policy and in Practice}

The literature in this review dates back to the 1980s when historic gardens were first recognized as heritage. Over these past four decades, both the ideologic foundations and the methodological instruments of historic garden management have evolved and grown in scope and complexity. The policy and professional deontology guiding historic garden management has gone from preserving "living monuments"[8] in the Florence Charter to managing dynamic landscapes in the European Landscape Convention [9]. This second approach is better equipped to recognize intangible heritage values, involve the community in heritage identification and management, and prioritize sustainability. However, a significant gap still remains between the ideal vision laid out in policy documents and what is actually achieved in practice. Not unaware, the academic community has sought to better understand and improve historic garden management, with each discipline proposing its own specialized methodologies and research tools. However, as this review has shown, research is not always based on an updated understanding of conservation thought.

When ICOMOS and IFLA jointly ratified the Florence Charter in 1982 [8], they officially added historic gardens to those heritage monuments and sites codified by the ICOMOS Venice Charter of 1964 [6]. The Florence Charter prioritized the identification and listing of historic gardens by trained experts. Thus, in the earlier years of historic garden research, the academic community was principally concerned with these tasks, as well as the possible actions (maintenance, conservation, restoration and reconstruction) admitted by the charter. In this literature review, the Florence Charter continues to be the most cited policy document. However, its influence is not always positive. While the Florence Charter represents an important advancement in heritage conservation, it is limiting if not complemented by other, more recent, documents in the heritage conservation canon.

Another important evolution in heritage policy is an increasing shift away from aiming to maintain historic gardens as unchanged as possible [8] towards managing change for sustainable development [9]. The former puts the most emphasis on one-time restoration projects carried out by experts and minimally considers management and upkeep. The latter puts the most emphasis on conservation management planning, where stakeholders (including experts, owner/managers and the community) guide both extraordinary and routine works. In order to aid both expert and non-expert stakeholders, policy is increasingly accompanied by operational guidelines such as those discussed by Cazzani et al. [12], which break down the complicated conservation management process into a cyclical series of strategic, operational and assessment phases. The effective difference such a tool makes can be seen in a comparison between Burmil's [71] and Halbrook's [74] case studies. While the former is not equipped by the Florence Charter to deal with change in the garden, the latter has a set of protocols provided by the US Ministry of the Interior's Guidelines [15] to confidently navigate the same kinds of problems. Furthermore, a conservation management view allows authors to define the management phase that they are addressing, without having to definitely resolve every problem. Indeed, given the scope and complexity of historic garden management, the latter would be impossible. Instead, operational guidelines focus on decision-making tools that can help prioritize the allocation of limited resources in a defined time-frame. Afterward, progress is assessed, and the cycle begins again.

The literature unequivocally showed that the principles of international guiding documents are most often not reflected in national, regional and municipal planning policy. At best, local authorities are adopting earlier policies such as the Florence Charter and focusing their attention on measures that protect listed gardens from development. While such efforts keep gardens from disappearing, they do not help gardens thrive. While the literature describes the problem, it does not find solutions. 
More pragmatic policy analysis is necessary that denounces less and investigates more. Public choice theory and other political economy approaches would be useful in better understanding the hows and whys of policy success and failure.

\subsection{Community Members and Stakeholders as the New Protagonists in Historic Garden Management}

Like the Athens and Venice Charter, the Florence Charter was concerned with identifying and saving monuments based on expert-attributed merit and did not see the public as stewards or stakeholders. With $82 \%$ of the literature in this review dedicated to describing the gardens themselves, i.e., supply, it is clear that the academic community embraced this role. However, around the same time that the Florence Charter was written, ICOMOS, as well as other bodies such as UNESCO, began to see experts as facilitators and not gatekeepers. Instead of deciding the value of heritage by themselves, they were given the responsibility of gauging the community's value for heritage sites and helping them care for them. This development was inspired by a recognition of the significance attributed to heritage by native peoples in documents such as the 1979 Australian ICOMOS Burra Charter [7] and the 2004 US/ICOMOS Natchitoches Declaration on Heritage Landscapes [102], as well as a desire to contrast globalization and the oppression of ethnic minorities in the 1994 ICOMOS Nara document [103]. As the European Union formed and sought a collective identity, it also played a leading role in recognizing historic urban areas and cultural landscapes as heritage assets, contributing to guiding documents such as the 2012 ICOMOS Valletta Principles [24]; the 2011 UNESCO Recommendations on the Historic Urban Landscape [99]; the 2015 ICOMOS Declaration on Heritage and Landscape as Human Values. These documents place the same primacy on community-attributed value and stewardship as those mentioned above. Legislation such as the UNESCO World Heritage Convention and the European Landscape Convention also incorporated a community-based attribution of significance, integrity and authenticity.

With policy documents universally calling for community involvement, the lack of research addressing this aspect is glaring. In this review, those studies that pay the most attention to community value and stewardship are categorized as demand [34,36-38] or both supply and demand [16,19,39-41] research. These studies use methodologies from the social sciences, such as survey questionnaires and interviews and economic appraisal techniques to investigate the community-attributed value of historic gardens. De Oliveira Paiva, de Brita Sousa and Carcaud [41] and Silva and Carvalho [34] give comprehensive presentations of research carried out within the field of Tourism Studies, while Askwith [16] provides various examples of economic appraisal methods. One might imagine that demand research has not been addressed much because historic garden scholars tend to come from Landscape or Cultural Heritage backgrounds. However, both Rostami et al. [36], from Engineering, Architecture and Built Environment, and Saeed et al. [38], from Agricultural Science, are both able to go outside the traditional confines of their discipline and conduct informative visitor surveys demonstrating the social and psychophysical benefits perceived by garden visitors and the wider community. The former also conduct a very thorough review of the literature evaluating the health and wellbeing benefits provided by urban nature and the social benefits provided by cultural heritage.

There are still many gaps in the literature regarding the demand-oriented study and community value of historic gardens. Monetary and non-monetary landscape appraisal methods are not being used, even though they have been developed for just this purpose [104,105]. These methods analyze demand through stated and revealed preference methods to estimate consumer surplus and quantify the positive externalities provided by non-market and public goods. Askwith's review gives a small but dated sample of these techniques. Today, they are commonly applied in the fields of Environmental, Ecological and Cultural Economics and Landscape Valuation, with many pertinent examples to be found.

Another important aspect of community value that is not addressed in the reviewed literature is equity. While there are many documented social benefits provided by historic gardens [36] that justify their support with public funding, studies have also repeatedly shown that historic garden visitors 
are predominantly wealthy, well-educated, older and female $[34,41,83]$. When confronting a similar problem in the arts, many cultural economists argue that culture is a merit good, i.e., a good that is more highly valued by society than by individual consumers because the latter are not fully able to understand its worth [96]. Both public and private expenditure on merit goods are motivated by altruism as well as a desire to improve one's own situation by improving community welfare [96]. Public resources are typically also spent on outreach to educate the public to increase their demand for those goods that increase their welfare, often focusing on the young and disadvantaged. Differentiated pricing also serves to lower the cost of merit goods to what consumer segments are willing to pay. Studies conducted on "plant blindness" [106,107] imply that education and outreach greatly impact visitors' appreciation and demand for nature experiences.

In heritage policy and practice, this outreach is called "interpretation". Some forms of interpretation common in cultural and natural heritage sites include signage, brochures, leaflets, exhibitions, visual displays, smell or touch stations, written or audio self-guided itineraries, expert-led guided walks, and interactive digital or web-based technology, among others. In this review, interpretation is considered by Counsell [23], who reviews some literature and guidelines on the subject and seeks to streamline the process from information recording to primary interpretation to secondary interpretation. However, much more could be done, especially regarding the effectiveness of interpretation in raising community attributed value or willingness to pay for historic gardens.

Internal stakeholders also merit attention as important members of the community. More than any other, the operational management phase regards the day-to-day struggles of garden owners, managers, gardeners and other staff. The lack of operational management research in the reviewed literature reveals that scholars maintain an expert-centered rather than stakeholder-centered focus. Any research truly interested in the sustainability of historic gardens must concern itself with those working to keep historic gardens afloat. As Brine and Feather [22] point out, the owners and managers of historic gardens are primarily motivated by a desire to conserve their property for future generations and share it with visitors, and not by profit. Indeed, as shown by Askwith [16], and Meda and Rinaldi [17], they are rarely able to make ends meet. Some authors hope to help historic garden staff work more efficiently with spatial information acquisition and management systems [12,23,44]. However, as Brine and Feather note, most heritage managers do not have the time or the technical skills necessary to learn to use these systems. Furthermore, they are not inclined to sit behind a computer and spend most of their workday in the field. However, smartphones may make data acquisition, compilation and retrieval increasingly accessible in the field, and a younger, more technology-savvy generation may be better equipped to use this technology. Other efforts made in the literature to improve efficiency are more immediately accessible, such as automated irrigation [43] and the use of standard management protocols [45].

Adequate staffing also emerges in the review as a significant problem, with Boisset [19], Sales [21], Thoday [20], and Albericci [18] all asserting that a well-trained, motivated, and adequately supplied gardening staff is the essential factor in historic garden management. Given that the same authors also identify a constantly worsening trend in this department, scholars must step up to fill the gap regarding historic garden staff. Research must better understand who is caring for our historic gardens and must find ways to requalify the figure of the skilled gardener in order to attract younger generations. The role of the media and garden celebrities has also not been investigated. Could the media contribute to making the professional figure of the master gardener relevant and respected? The profession of the chef, which is similar in many ways, was also once considered menial but is now attracting increasing attention and prestige thanks to mediatic attention [108].

\subsection{Sustainability of Historic Gardens}

Created by the combined forces of man and nature and necessitating continual resources to survive, historic gardens represent a perfect union of the social, economic and economic pillars of sustainability. In light of this and the increasing relevance is given to sustainability by such heritage 
policy documents as the European Landscape Convention and the UN Sustainable Development Goals, the literature in this review is categorized according to these three aspects of sustainability processes.

The literature shows that historic garden management studies are strongly focused on social sustainability. However, much of this research only regards the social sustainability of material heritage and not the social sustainability of political systems, intangible culture, or wellbeing. Rostami et al. [36] provide a good review of the literature regarding all aspects of social sustainability; Phillips [75], Abdel-Rahman and Nourhan [68], and Mahdizadeh and Rajendran [65] specifically investigate the sustainability of the political institutions governing historic garden conservation; Gao and Dietze-Schirdewahn [10] address the sustainability of intangible culture in historic gardens. Future research should follow the lead of these authors and look beyond the conservation of material heritage when addressing social sustainability.

Wellbeing is an especially important topic at the moment. A host of literature exists demonstrating the contribution made to wellbeing by urban green spaces and cultural heritage. Research on urban parks and gardens has shown how they contribute to health by providing outdoor areas for play and sport, increasing the amount people walk, reducing stress, and promoting relaxation [104]. They also contribute to a healthier and more pleasant urban environment by reducing the heat island effect, noise pollution, and atmospheric pollution [109]. Cultural heritage in cities is also increasingly recognized as a necessary component of urban life, contributing to creating a sense of place, pride and attachment and belonging, community stability, social infrastructure and capital, and security [36]. While historic gardens surely contribute both sets of benefits, research is missing regarding their special contribution to wellbeing. Historic garden researchers should not be content to only cite studies from other subjects quantifying the psychophysical health benefits of nature and culture; they must pursue these areas themselves.

The economic sustainability of historic gardens is also woefully underrepresented in the literature. While Silva and Carvalho [34] and de Oliveira Paiva, de Brito Sousa and Carcaud [41] give information and estimates on the income generated by garden tourism, only Askwith [16] and Pérez-Urrestarazu et al. [43] even mention the costs of historic gardens. While the former studies provide important information on the general historic garden market, the costs of individual tourist gardens must be known in order to understand how much income gardens need to generate in order to break even. This must then be considered along with marketing segmentation issues [110] and visitor carrying capacity [111] in order to strategize for an optimum number of visitors who will financially support gardens without irreparably damaging them. In his monograph on garden tourism, Richard Benfield discusses these considerations and also notes that historic and botanical gardens are being increasingly asked to be economically self-sufficient through visitor-induced revenue [112]. However, as both Benfield and Tempesta note, historic gardens are public and merit goods and therefore will always be undervalued by consumers [104,105,113]. According to these authors, they cannot survive without government or philanthropic sponsorship. One reason why UK historic gardens are so lauded in the literature is the relative success achieved by such economic incentive programs as the National Lottery Fund and the intervention of private nonprofit entities such as the National Trust. While UK focused research exists documenting these successes (e.g., Harney [114]), examples from other regions and nations would be illuminating. The economic effects of public command, control and incentive measures, as well as private nonprofit intervention, should be a topic for future study. As Tempesta emphasizes, it is essential that the effectiveness and efficiency of these public or philanthropic interventions be evaluated through cost-benefit analysis [105] in order to assure that public spending is truly increasing welfare.

While the literature review shows that researchers are quite interested in historic gardens contribution to environmental sustainability, until now these investigations have mainly concentrated on gardens' role in maintaining biodiversity by providing habitat for both important native species as well as botanical cultural relicts. This connection between cultural and biological diversity and richness is certainly important, especially considering the habitat loss caused by urbanization. However, in light 
of the growing concern over urban resilience, growing populations and climate change, these subjects should also be specifically addressed by future historic garden studies.

Ecosystem services are an emerging research subject that seeks to combine all three sustainability pillars in an ecologically and economically founded conceptual framework. They were originally defined by the Millennium Ecosystem Assessment as "the benefits people obtain from ecosystems. These include provisioning services such as food, water, timber, and fiber; regulating services that affect climate, floods, disease, wastes, and water quality; cultural services that provide recreational, aesthetic, and spiritual benefits; and supporting services such as soil formation, photosynthesis, and nutrient cycling,"[115]. While the specific nomenclature of these services is still being revised, the concept of assigning a market value to ecological functions to better inform policy and decision-making remains the same. In general, ecosystem services are assigned a total economic value (TEV), comprised of a use-value and a non-use value. Neonato, Tomaselli and Collanino's review provides an initial example of applying Ecosystem Services to historic gardens and other urban green areas [109].

\subsection{New Regions and Cultures}

Although historic garden management literature was concentrated in Europe in the past, where interest in environmental and cultural heritage was a reaction to the losses suffered during the World Wars [5], research is now also coming from Asia, North Africa and South America. This trend may be in response to a greater interest in wellbeing and leisure, a desire to assert a non-colonial national identity or a perceived risk of losing heritage. In any case, these non-Eurocentric studies have much to contribute. They are not only informative because they shed light on previously unexplored landscapes but also because they seem less inhibited in criticizing their national heritage policy and planning measures. European researchers should be inspired by these studies to critically evaluate the effectiveness and efficiency of their national policy and planning system and take a public-choice view of political actors.

In this review, we have also seen that significant inter-European differences remain to be explored regarding historic gardens and their management. For example, Silva and Carvalho [68] show the differences between the historic garden visitor in Portugal compared to the historic garden visitor in the United Kingdom. Nationwide tourism market studies should be conducted by researchers in order to provide more appropriate and accurate benchmarks for individual gardens. These should be conducted in line with standardized statistical methodologies and sampling scales so that useful comparisons can be made. This review focuses on mainstream scientific publications by selecting literature from the prominent interdisciplinary scientific databases Scopus and WoS. While this choice allows for a panoramic perspective of an already complicated subject, it also may have excluded more locally relevant literature. Future country-specific studies should be more inclusive and look into smaller publications in different languages as well as gray literature.

\subsection{New Methods and Disciplines}

One of the principal goals of this literature review is to identify the research methods and instruments that can best contribute to historic garden management study and indicate where underused methodologies would be particularly valuable. One of the most important such methodologies are those of Resource Economics and Appraisal. In the only reviewed study regarding economic methods, Askwith laments that "those concerned with the conservation of historic parks and gardens have been chary of quantifying their value, fearing perhaps that such an approach, taken in extremis might lead to knowing the price of everything and the value of nothing"[16]. This still seems to be the case. Economic appraisal methods are useful for more than just finances. They investigate community value, the allocation of scarce resources and optimization of wellbeing. Furthermore, they translate these complex considerations into pragmatic, solution-oriented terms.

Cost-benefit analysis studies are particularly useful for showing the lack of public resources invested in heritage and their often inefficient allocation, with contingent valuation studies continuing 
to be a preferred method for evaluating the total economic value of both natural and cultural heritage. There are various stated and revealed preference methods that evaluate value in both monetary and non-monetary terms. Historic gardens should be ideal candidates for these methodologies, especially because authors have noted that public administrations tend to undervalue and under-support them. Quantifying their value to the community is a first step in resolving this problem, especially for public gardens. A comparison of costs and benefits should also be part of any feasibility study for tourist gardens within the strategic phase of management. The investigation of performance indicators, such as those used by Pérez-Urrestarazu [43], would also contribute to a better understanding of historic garden management efficiency, even when making choices such as those suggested by Thoday [20] to maintain traditional husbandry practices. As a recent doctoral thesis [116] has shown, traditional gardening methods may sometimes be more efficient than imagined and also contribute added esthetic, ecological, and cultural value.

While methods from Tourism Studies are better represented in the literature review, some gaps in the literature include visitor surveys conducted in different geographic areas and in different kinds of gardens; stocktaking on the number of sites, their ownership, their visitor flows, and their financial balance; studies on carrying capacity assessment; content analysis comparing visitor reviews or garden interpretation material to garden mission statements. New technology using mobile phones and tracking data may make tracking visitor flow and mobility much easier.

As for environmental research methods, biodiversity concerned field studies continue to be important tools for evaluating historic gardens' ecological value as urban habitat. These can be used to calculate and analyze various ecological indicators such as species number, diversity, richness, or number of IUCN Red List species. As mentioned above, the growing field of ecosystem service evaluation offers an interesting way to combine ecological and economic analysis. In addition to biodiversity and habitat, future studies should further investigate the impact historic gardens have on the urban environment, including climate, water-flow, air and soil quality, nutrient cycles (especially carbon), and noise. Other factors such as human health and wellbeing and resilience to climate change should also be further investigated. Research is also needed that investigates the different environmental impacts of different types of historic gardens in a wider array of geographic, climatic and sociocultural contexts. Researchers should not be content to cite the same studies as a benchmark for everything (for example American forestry data are often used to estimate ecosystem services throughout the world [109]), but must achieve more detailed and specific measurements.

Regarding the methodologies from cultural studies and architecture, historical analysis and case studies are well represented in our review. These published studies are invaluable for the owners and managers of historic gardens, who often lack the resources and expertise to dedicate to archival study and detailed site analysis. However, as noted by Brine and Feather [22], this information often does not reach those who need it most. Authors of the reviewed literature concerned with GIS information systems and computer modeling attempt to resolve this problem by creating applications that can manage information both for managers as well as for the public. However, any such research should also address garden managers lack of technological skills and need to be in the field. The contribution of smartphones and apps that use their incorporated geographic positioning system (GPS) should be investigated in this regard.

Historic gardens are located at a nexus between nature and culture, making them a particularly fascinating and rewarding laboratory for the disciplines of Museology, Heritage Interpretation, and Environmental Education. Interpretation should also be studied from an economic standpoint, as it adds significant value to the visitor experience if done well, allowing visitors to perceive a wider array of tangible and intangible benefits. Future research may include economic estimates of that perceived benefit, along with a better understanding of how to assess the quality and effectiveness of heritage interpretation in a historic garden. 
Finally, it should be noted that most historic garden research has addressed tourist gardens and not public or private gardens. Efforts should be made to address all three typologies and to distinguish each one's particular characteristics and needs.

\section{Conclusions}

This is undeniably a particular moment to be taking stock. Today, in the midst of a global pandemic with dire consequences for human wellbeing and the economic sustainability of heritage conservation, regard for historic gardens seems particularly vital. The tourism revenue that normally economically supports these gardens has been curtailed, while the labor supply that maintains them is being constantly interrupted. Indeed, historic gardens share many of the threats and weaknesses identified by the UN World Tourism Organization (UNWTO) for the Tourism sector in this crisis [117], but also present important strengths and opportunities. These outdoor spaces provide rare occasions for contact with nature and fellow-man while social distancing is necessary. In light of their heightened vulnerability and importance at this moment, research should draw attention to their many benefits and investigate management strategies and tools that will aid their survival.

While it is still too soon to evaluate the consequences of the Covid-19 pandemic, it will surely be a watershed moment for mankind. The lasting effects of this global natural experiment will not be all bad if researchers can find opportunities to understand how historic gardens can better contribute to wellbeing. At a time when public funding is being spent at unprecedented levels to confront the world's health and economic crisis, decision-makers should be convinced that investments in historic gardens are money well spent and that these spaces are valuable resources for recovering from this crisis, as well as for preventing future calamities. Their many ecosystem services contributing to a resilient and thriving urban environment should be protected and promoted. They also should be some of the first urban tourism attractions ready to safely accommodate visitors increasingly interested in wellness and nature, and thus important contributors to the economic recovery of historic city centers. Quarantine and isolation measures have especially impacted social connections and education, highlighting the social value of historic gardens. Their associations with historic events and people foster a sense of community identity and cohesiveness. They promote both physical and mental health through simple pleasures such as pleasant walks and scenic beauty. They are rich with educational value, microcosms from which the whole world can be examined and explained to students and enthusiasts alike. Recent studies show how these benefits have been increasingly valued during the pandemic and duly missed when quarantine measures have made them inaccessible [118]. However, all of these social, cultural, environmental and economic benefits must be known if they are to be guaranteed, and they must be studied and communicated according to empiric scientific methods that are precise, unbiased and easily understood by decision-makers.

In order to do so, historic garden researchers must leave behind the expert-driven approaches of the past and find new ways to give a voice to the community and the internal stakeholders that support historic gardens. That is not to say that experts do not have a role. They should use their knowledge to help community members better understand and appreciate historic gardens and advocate for more effective, efficient and equitable policy measures. In this review, Social Science methods from the fields of Resource Economics and Appraisal, Tourism Studies and Urban Heritage Studies are all at the forefront of new explorations in this direction. Future research should continue to build on the general framework and themes analyzed here, focusing on more specific subjects, regions and methods. Indeed, historic gardens offer many opportunities to explore new territory and new methods from paradises that may be overlooked in our very own neighborhoods.

Author Contributions: Conceptualization, C.F.; methodology, C.F.; validation, C.F., V.B. and E.S.; formal analysis, C.F.; investigation, C.F.; data curation, C.F.; writing — original draft preparation, review and editing, C.F., V.B. and E.S.; supervision, E.S. All authors have read and agreed to the published version of the manuscript.

Funding: This research was supported by research funds granted by the Università degli Studi di Palermo's D071-Scienze Agrarie, Alimentari e Forestali Ph.D. program. 
Acknowledgments: The authors would like to thank Robert Peel for his reading of the paper and thoughtful suggestions.

Conflicts of Interest: The authors declare no conflict of interest.

\section{Appendix A.}

Here, an overview of each study can be found that includes the main analysis criteria of our review. Studies are divided into subsections by use group. Within each group, studies are listed chronologically.

\section{Appendix A.1. General Gardens}

In her 1980 article, "Management of historic gardens-their role in the present and future as public amenity areas" [19], Boisset considers what constitutes a garden historic and what should be prioritized in its management. From a UK perspective, she discusses the growing trend in public leisure, financial aspects of garden management, and the maintenance plan. Her publication considers both supply and demand, involves the strategic and operational phases of management and addresses social sustainability.

Krosigk's 1987 article, "Preservation and maintenance of historic gardens and parks in West Germany" [63], examines the development of the legal framework and attitudes towards historic gardens in Germany during the arc of the 20th century. His study focuses on supply, involves the strategic phase of management, and regards social sustainability.

Askwith's 1999 review article, "The economic contribution of historic parks, gardens and designed landscapes: A review of existing data and research and recommendations for future research" [16], looks at research and gray literature seeking to quantify the economic value of tourist, public and private historic gardens as products, as consumers of goods and services, as public goods outside the marketplace, and as catalysts promoting local regeneration. Askwith refers to public and private entity audits, UK national statistics, tourist board market research, and academic studies using such methodologies as direct and indirect non-market valuation (travel-cost, hedonic pricing, and contingent valuation), market research (discussion groups, interviews, on-site and household survey questionnaires); tourist board statistics. She considers both supply and demand perspectives. Her study involves the assessment phase of management and primarily concerns economic sustainability, but also considers aspects of social sustainability.

Sales's 2000 article "Conserving historic gardens" [21] discusses conservation strategy and planning as well as key issues such as significance, restoration, management, the periodic replacement of vegetation, and staffing. His study is supply-oriented, involves both the strategic and operational phases of management and regards social sustainability.

In her 2005 article "Study of a historic garden soil at the Grand-Pressigny site (Indre-et-Loire, France): evidence of landscape management" [69], Vissac uses soil profiles at a case-study site from the 15th-18th-century. The author shows how different anthropogenic levels, as well as carbonate, phosphorus, carbon organic contents and soil porosity (image analysis) readings, can provide evidence of previous ornamental garden management. This is a supply study that involves the strategic phase of management. Although environmental data are analyzed, these data are used to reconstruct the social use of the space, thus we would consider this paper as primarily pertaining to social sustainability.

Kowarik and Wohlgemuth's 2006 article, "Tulipa sylvestris (Liliaceae) in Northwestern Germany: a non-indigenous species as an indicator of previous horticulture" [49], investigates a positive side of the biological invasions of historically and culturally significant plant species. It is a supply study involving the strategic phase of management. The author emphasizes that the wild tulip is a listed species and historic gardens are important conservation sites. Thus, the article primarily regards environmental sustainability.

Phillips's 2014 book chapter “The international context - the European Landscape Convention" [75], discusses the European Landscape Convention's history, the importance the treaty has had in defining cultural landscape terminology and objectives and briefly touches on the government bodies and NGOs 
responsible for its implementation in the UK. The chapter regards the government's role in assuring the supply of historic landscapes, involves strategic management and regards social sustainability.

In his 2014 Book Chapter "Science and craft in understanding historic gardens and their management" [20], Thoday discusses the intrinsic connection between the cultural value of a garden and the methods used to manage it. The author proposes a rule to guide decisions: to seek to achieve the original design intent of the garden as well as the objectives of the current owner. He also discusses the key role of craft in garden conservation, arguing that a well-conserved garden should consider historic husbandry practices where appropriate. Thoday's chapter is supply-oriented, involves the operational phase of management and regards social sustainability.

Thorne's 2014 Book Chapter "Costing and contracts for historic gardens and landscapes" [42] regards the three parties involved in a historic garden contract: the client, the designer and the contractor. Thorne discusses the important issues that should be kept in mind by each party regarding the "commissioning, designing, financing, implementation, and management and maintenance of historic landscape projects" [42]. His contribution is supply oriented, involves the operational phase of management and regards economic sustainability.

In Khalilnezhad's 2017 conference paper, "Principles of integration of the agriculture and pleasure greeneries in Persian gardens" [64], the author uses the site and historic document analysis to identify the main architectural principles guiding the layout of decorative and productive elements in Persian gardens. The paper is supply-oriented, regards the strategic management phase and social sustainability.

In their 2018 article, "A renewed approach to conservation policy of historic gardens in Iran" [65], Mahdizadeh and Rajendran trace the history of historic garden policy and perception in Iran by examining primary documents from the nation's various political eras during the 20th-century. Their study regards supply, the strategic phase of management, and social sustainability.

In the 2019 book chapter, "Revitalisation of historic gardens-Sustainable models of renewal" [50], Obad Šcitaroci et al. seek to identify "renewal" models for historic gardens that ensure protection and economic sustainability and maintain or enhance cultural heritage value. The authors base their hypothetical renewal models on three Croatian case studies: the gardens of the summer villas in Dubrovnik, historicist gardens in Opatija, historicist spa gardens in northern Croatia. This study regards supply, the strategic management phase and social sustainability.

Gullino, Devecchi and Larcher's 2020 article "New sustainable approach for historic garden restoration: the case study of Ludwig Winter's gardens in Liguria Region" [59] proposes a methodological framework for historic garden restoration and applies it to two historic gardens in Liguria (Italy). The two sites were designed by the German horticulturalist Ludwig Winter, who was well known for introducing new exotic ornamental plant species, such as Phoenix canariensis Chabaud. These palms, in particular, have been killed throughout the Mediterranean by infestations of the red palm weevil (Rhynchophorus ferrugineus Oliver). A historic study of primary documents is conducted to establish the original planting plan and species list of the two gardens in question, as well as other public and private gardens designed by Ludwig Winter. Plant specimens in the two gardens are then replaced with species that are historically correct but less susceptible to pest infestation. The study is supply-oriented and regards strategic management and environmental sustainability.

\section{Appendix A.2. Public Gardens}

Maurer, Peschel, and Schmitz's 2000 article, "The flora of selected urban land-use types in Berlin and Potsdam with regard to nature conservation in cities" [55] analyzes the urban flora of three different land-use types in the metropolitan area of Berlin: that of historic landscape parks in SW Berlin; residential areas built between 1925-1934 in NE Berlin; the wasteland at the site of the former wall dividing East and West Germany, at the center of Berlin. A field survey counting wild-growing vascular plant species and IUCN Red List species is used as an indicator to explore natural and historical heritage value and is compared with the history of each site's management. Based on their 
findings, the authors identify the following principles for natural and historical heritage conservation planning in the urban environment: historical continuity, maintenance of local varieties, maintenance of land-use diversity, and urban-ecological zonation. The article is supply-oriented, involves the assessment management phase and regards environmental sustainability, although aspects of social sustainability are also considered.

Ionescu, Iliescu and Dumitrascu's 2010 Conference paper, “Historical garden as cultural identity mark in Bucharest urban landscape-Case study: the Kiseleff road and garden" [72], identifies seven historic garden sites and describes their historic, social, and ecological value. Primary historical documents, informal interviews, pollution data, and phytosanitary evaluations of historic trees are discussed for each site. The paper is supply-oriented, regards the assessment phase of management and primarily addressed social sustainability, although environmental sustainability is also discussed.

In their 2015 article, "Sustainable cities and the contribution of historical urban green spaces: a case study of historical Persian gardens "[36], Rostami et al. analyze the social benefits provided by four historic Persian gardens through a sequential mixed method inquiry combining on-site observational studies, semi-structured interviews and surveys. Their article is demand-oriented, regards the assessment phase of management, and regards social sustainability.

Wahurwagh and Dongre's 2015 article, “Burhanpur cultural landscape conservation: Inspiring quality for sustainable regeneration" [70], criticizes the poor management of the Historic Urban Landscape of Burhanpur as being responsible for the loss of traditional natural resource management and planning systems, as well as architectural traditions. The authors argue that exactly this cultural heritage, "with its indigenous planning, design and building practices, including historic gardens and water management systems" [70] could be the key to sustainable development, basing their analysis on the work of Francesco Bandarin and Ron Van Oers [119], the 2005 Vienna Memorandum [120], and the 2011 UNESCO Recommendations for the Historic Urban Landscape [99]). The article is supply-oriented, strategic, and equally interested in environmental and social sustainability.

In her 2016 conference paper, “Egyptian historical parks, authenticity vs. change in Cairo's cultural landscapes" [68], Abdel-Rahman analyzes the initial design, development and current state of 10 publicly accessible historic parks and gardens from the 19th and 20th century that she deems worthy of preservation. The paper is supply-oriented, regards strategic management and social sustainability.

In their 2017 article, "Train station area gardens: the creation and evolution of Dr. José Esteves Square, in Lavras-MG" [39], Luz, Paiva, and Alves study the history of a public square in Brazil from 1721 to the present, using primary documents, informal interviews and current site analysis. A historic 2-D reconstruction of the space at the time of its inauguration was also drawn. Their study is both supply and demand-oriented, strategic, and regards social sustainability.

In their 2019 conference paper, "Management plans and web-GIS software applications as active and dynamic tools to conserve and valorize historic public gardens" [12], Cazzani, Zerbi, and Brumana discuss the role of GIS applications in the management of public historic parks. They discuss case studies of historic gardens that were once private estates but are now publicly owned and managed. They also propose low-cost open-access web-GIS applications to organize the large amount of information involved in the management process and to possibly make it accessible to the public. Their paper is supply-oriented, regards strategic management and social sustainability.

\section{Appendix A.3. Tourist Gardens}

Burmil's 2000 article, "Issues in the conservation of gardens in Israel: Ramat Hanadiv as a case study," [71] analyzes the Ramat Hanadiv memorial garden. The author first establishes that the garden is indeed historic, according to the principles of the Florence Charter and then explores possible management actions, including conservation, restoration, or rehabilitation. The study is supply-oriented, concerned with the strategic management phase, and with social sustainability.

Counsell's 2001 conference paper "An evolutionary approach to digital recording and information about heritage sites" [23] investigates the use of spatial information systems to store, manage, 
and provide access to interpretive information on historic sites. Counsell notes challenges in data acquisition and recording particular to historic gardens, including the rapidity of change; the need to use recorded information for both primary and secondary interpretation; lack of resources to acquire information; lack of a clear information supply sequence "from data through understanding to explanation" [23]; lack of technical proficiency in garden history specialists; accessibility of interpretation material for visitors. The author shows how these challenges are addressed in three case studies: the Tower of London Environs Models; Hortonet; the Valhalla project, an information exchange portal between the gardening staff of two prominent historic gardens in the United Kingdom and in France (Hatfield House and the Chateau de Villandry). Counsell's paper is supply-oriented, involves the assessment management phase and social sustainability.

Halbrooks's 2005 article, “The English Garden at Stan Hywet Hall and Gardens: Interpretation, analysis, and documentation of a historic garden restoration" discusses the steps taken to develop a preservation treatment plan for a historic garden in Akron, OH, (USA) according to the United States Secretary guidelines for the treatment of cultural landscapes [15]. The article is supply-oriented, involves the strategic management phase, and regards social sustainability.

The following five conference papers were delivered at the 2005 "The Botanical and Historic Garden, a cultural good serving the community" national congress held by the Italian Botanical Society (Historic and Botanical Garden Working Group).

Albericci's paper "Issues relating to the technical management, the lack of specific skills and the professional training of staff working in botanic gardens and historic parks" [18] discusses the shortage of qualified personnel in Italian historic gardens. The author notes that as older gardeners retire, they are replaced with less qualified temporary labor, subcontracts to unspecialized landscaping companies, or not replaced at all. While university programs in historic and botanical garden management exist, they focus on upper management, while the training and employment of those that must physically practice the craft of gardening have not been addressed at all. The paper is supply-oriented, involves the operational management phase and regards both social and economic sustainability.

Cappelletti's paper "A historical botanic garden, UNESCO World cultural heritage: opportunities and problems" [58] discusses the management plan of the Padua botanical gardens and the construction of an adjunct satellite garden to allow the institution to respect both their current educational and scientific activities while maintaining the authenticity and integrity of the original site. The paper is supply-oriented, involves the strategic management phase and regards social responsibility.

Gratani's contribution, "Didactic Functionality-the Botanical Garden of Rome" [40], discusses the management strategies of the Rome Botanical Garden in accordance with the Global Taxonomy Initiative to ensure the sustainable use of biodiversity. Some visitor statistics collected between 2001 and 2004 are also presented. The article takes both a supply and demand perspective, considers the assessment phase of management and regards both social and environmental sustainability.

Meda and Rinaldi's paper, "Management and opening to an extra-university public of university botanical gardens, synthesis of a self-evaluation on a questionnaire base" [17] presents the results of a questionnaire filled out by 13 managers of Italian University Botanical Gardens. Meda found that many Botanical Gardens must rely on external contracts for extraordinary maintenance and visitor services, increasingly need to implement an entrance fee, do not manage an independent budget and for bureaucratic reasons have difficulty raising external funding, and have an annual budget ranging from 4500-80,000 euros. The paper is supply-oriented, involves the assessment phase of management and regards economic sustainability.

Tisi's "Making the most of educational experiences in historical and botanical gardens in Trentino" [61] discusses the educational activities provided by the Tridentino Museum of Natural Sciences in Trentino, Italy, carried out in two of its Botanical Gardens (the Viotte Alpine Botanical Garden and the Arco Arboretum) as well as in various public and private historic gardens in the Trento area (the public gardens of Garbari, Piazza Dante, and Arco, as well as the private gardens of Villa Margone, De Probizer Park, Palazzo Guerrieri Gonzaga, and Villa Angerer). The author describes 
each garden's history, flora, examples of interpretative activities carried out for schools as well as the wider public and provides some exemplative visitor numbers. The paper is primarily supply-oriented, involves the assessment phase of management, and regards social sustainability.

In their 2008 article, "Lichen recolonization on restored calcareous statues of three Venetian villas" [60], Nascimbene and Salvadori evaluate lichen recolonization after restoration on statues in the gardens of three Venetian villas with different environmental conditions. They show that intensive restorative cleaning practices are not effective ways of conserving the artwork because lichen always recolonizes the statues at a very high rate. They hypothesize that a regular maintenance program would be more effective. The article is supply-oriented, involves the assessment phase of management, and primarily regards social sustainability, although environmental sustainability is also discussed.

Todt, Herder and Dabija's 2008 article, "The role of monument protection for tourism" [37], discusses cultural monuments as economic goods. The author explains that their economic value can be observed in the public and private resources spent on maintenance and conservation and the money consumers spend in order to visit them. This value, according to the authors, is primarily related to identity. The authors also discuss the Venice Charter and the UNESCO World Heritage Convention's different qualifications for attributing cultural value, monuments as pure public goods, and the competitive advantage that they give cities. The article is mostly demand-oriented, involves the strategic phase of management, and regards economic sustainability.

Cavagnero and Revelli's 2009 article, "Numerical model application for the restoration of Racconigi Royal Park (CN, Italy)" [57], applies a numerical hydraulic model to plan the restoration of waterways within a historic garden and UNESCO site without altering the historical layout. Based on the model simulations, water flow is adjusted on the site, and maintenance efficiency is improved. The article is supply-oriented, involves both the strategic and operational management phases, and primarily regards environmental sustainability.

Brine and Feather's 2010 article, "The information needs of UK historic houses: mapping the ground" [22], analyzes the information-seeking behavior of historic estate managers. As noted by other authors [12,23], information documentation, analysis and interpretation are key steps in the management process. Based on literature review, postal questionnaires and face-to-face interviews, the authors elaborate a model for how heritage estate owners/managers approach their information needs called the "trusted source" model of information-seeking behavior. The article is supply-oriented, involves the assessment phase of management, and mostly regards social sustainability with some economic implications.

In their 2012 article, "The relationship between landscape design style and the conservation value of parks: a case study of a historical park in Weimar, Germany" [56], Kümmerling and Müller investigate the biological conservation value of a landscape park in Weimar, Germany, and discusses plant and habitat biodiversity as a criterion for management. They conduct a field survey of the flora in the different habitats present in the park. Their article is supply-oriented, involves the assessment management phase, and primarily regards environmental biodiversity. Social sustainability is also touched on.

In their 2012 Conference paper, "The manner of rehabilitation of historical vernacular gardens (case study is Ali Abad Garden in Bojnourd-Iran)", Mahmood and Nasim [66] discuss how a historical Persian garden may be "rehabilitated" in order to promote local regeneration and tourism. They base their conjecture on historical documents and analysis of the ruins of a historic garden in Bojnourd, Iran. Their paper is supply-oriented, involves the strategic phase of management and regards social sustainability.

Bergande and Markstein's 2013 conference proceedings, "A preservation and management plan for the Botanic Garden Berlin-Dahlem" [62], presents a preservation and management plan commissioned by the Historic Gardens Conservation Unit of the Berlin Historic Buildings and Monuments Commission in 2006. The authors also investigate how the overlapping roles of a historic botanical garden can be dealt with through management planning that considers the ecological and heritage value of 
specific sectors and prioritizes the resolution of use-conflicts accordingly. The paper is supply-oriented, involves the strategic phase of management and regards environmental sustainability, although social sustainability is also considered.

In her 2013 article "The Austrian Federal Gardens and their plant collections-historic garden monuments, cultural heritage, recreational spaces and tourist attractions" [67], Mang discusses the Austrian Federal Gardens, the managing body of seven of Austria's most important historic gardens. Current management practices and issues are summarized. The article is supply-oriented, involves the assessment management phase and regards social sustainability, although economic sustainability is also touched on.

In Hansen, Thomsen, and Rasmussen's 2014 article, "DNA markers provide insight about common lime in historical plantings—an example from the Royal Danish Gardens", the authors address the problem posed by replanting trees in historic gardens with historically appropriate plant material. They genetically profile felled common lime trees (Tilia cordata) planted in 1760 in the Royal Danish Gardens and identify the closest nursery clonal material available. In 2014, the authors estimated a cost/tree of about 10 euros for this procedure. This kind of testing could contribute to the archive-based practices currently used to identify historical plant material with an easily carried out verification process. The article is supply-oriented, involves the strategic phase of management, and regards social and environmental sustainability in equal measure.

In Saeed et al.'s 2017 article "Historic gardens can attract more visitors by the provision of more facilities: A case study of Three Mughal gardens of Pakistan" [38], the authors investigate the facilities of three historic Mughal gardens in Pakistan through a visitor survey. A structured questionnaire is administered by an interviewer on site. The authors adopt a selection strategy used in a rural tourism study in Turkey (see Akin et al., 2015 cited in [38]) where adult ( $>18)$ visitors are approached after one hour for an interview. If visitors refuse, the next visitor is approached until the sample target (200) is reached. Data are gathered on the sociodemographic characteristics of visitors (number per garden, age group, education level); visitor satisfaction for overall garden management; satisfaction of visitors for common available facilities; demand for more facilities by the visitors (library, bookshop, antique shop; all); visitor rating of utilities available in the garden; visitor ratings of the canteens in the garden; visitor rating of the perceived safety and security in the garden; visitor rating of the available parking for the garden. The results are analyzed according to frequency and contingency tables. The article is demand-oriented, involves the assessment phase of management, and regards social sustainability.

In Ciaffi M. et al.'s 2018 article. “Conservation of veteran trees within historic gardens (COVE): a case study applied to Platanus orientalis L. in central Italy" [45], the authors apply the interdisciplinary conservation of veteran trees within historic gardens (COVE) protocol to identify, maintain, and replace the monumental plane trees of Villa Lante, in Bagnaia. The article is supply-oriented, involves the strategic phase of management and regards both social and environmental sustainability.

Pérez-Urrestarazu et al.'s 2018 article, "Water management assessment in a historic garden: the case study of the Real Alcazar (Seville, Spain)" [43] analyzes water management in the Real Alcazar in Spain. This Historic Garden complex was chosen as a case study because it is made up of 20 gardens, with a total area of about 7 hectares, built in different styles and periods (XII-XX C.). 6 performance indicators are used to understand and evaluate the gardens' water use and efficiency: relative water supply (RWS); relative rainfall supply (RRS); relative irrigated area (RA); total management, operations and maintenance cost per unit area (MOMa) $\left(€ \cdot \mathrm{m}^{-2}\right)$; total management, operations and maintenance cost per unit volume supplied $(\mathrm{MOMv})\left(€ \cdot \mathrm{m}^{-3}\right)$; labor per unit area $(\mathrm{PA})$ (person $\cdot \mathrm{ha}^{-1}$ ). These indicators are estimated during two periods of the irrigation season: the lower intensity spring-autumn period and the higher intensity summer period. An evaluation of these indicators shows where automated and manual flood irrigation proves more efficient and how water management could be improved. The last three labor-related indicators are especially important for historic gardens, where gardener skill and availability have been noted to be serious problems. 
This study is supply-oriented, involves the assessment phase of management, and primarily regards economic sustainability, although environmental sustainability is also considered.

Alves et al.'s 2019 Book chapter, "Restoration of the Masonry Arch Bridge Over Jamor River in the National Palace of Queluz" [33], describes the restoration of the 18th-century masonry arched bridge in 2012, within the Portuguese national monument, the Queluz National Palace and Gardens. The article is supply-oriented, involves both the strategic and operational phases of management, and regards social sustainability.

Malinverni, Chiappini and Pierdicca's 2019 conference paper "A Geodatabase for multisource data management applied to cultural heritage: the case study of Villa Buonaccorsi's historic garden" [44] presents the application of an open-source GIS information acquisition and management system at Villa Buonaccorsi in Potenza Picena (MC, Italy). The paper is supply-oriented, involves the strategic phase of management, and regards social sustainability.

Oishi's 2019 article, "Urban heat island effects on moss gardens in Kyoto, Japan" [51], investigates the effect of the urban heat island effect on traditional Japanese gardens using moss as a groundcover. The authors study 17 historic gardens in Kyoto, Japan, conducting a field survey of the moss cover types, measuring temperature and humidity as well as the surrounding land-use type. Based on the results, the author recommends a buffer zone of $1 \mathrm{~km}$ around moss gardens to mitigate the urban heat island. The article is supply-oriented, involves the strategic phase of management and regards environmental sustainability.

Silva and Carvalho's 2019 book chapter, "Visiting gardens in Portugal: Profiling the historic gardens visit, and visitors," [34] investigates historic garden tourism in Portugal from a demand point of view. The authors aim to collect data on the socioeconomic and demographic profile of historic garden visitors, as well as their interests, motivations, visiting habits and behaviors. Through data analysis, they also aim to show differences and relationships between garden types, and visitor types, behavior and demand. They administer a face-to-face survey questionnaire to a sample of 666 visitors in three Portuguese historic gardens (the Serralves Park in Porto; the University of Coimbra Botanical Garden in Coimbra and the Frontiera Palace Garden in Lisbon). The results are not only interesting on their own but especially noteworthy when compared to similar studies performed in the United Kingdom. The chapter is demand-oriented, involves the assessment phase of management, and primarily regards social sustainability. Aspects of economic sustainability are also discussed.

Arteaga et al.'s 2020 article "Arthropod diversity in two historic gardens in the Azores, Portugal" [53] investigates the arthropod community in two different historic gardens in the Portuguese Azores: the Faial Botanic Garden and the Duque da Terceira Garden. The authors find that the Botanical Garden, with more native plant species, also contains more native and endemic arthropod species. However, The Duque da Terceira garden, with more introduced plant and insect species, has a higher species diversity richness overall. From a management perspective, the authors argue that management planning and practices should be based on species-specific cases because success depends on each species' own abilities and needs. They propose that a culturally relevant indicator species could be selected as a way to measure and manage for both the natural and human community. The article is supply-oriented, involves the assessment phase of management, and regards environmental sustainability.

De Oliveira Paiva, de Brito Sousa and Carcaud's 2020 review "Flowers and gardens on the context and tourism potential" [41] looks at the literature regarding various aspects of garden tourism. They address garden visiting in general, botanic gardens, historic gardens, contemporary gardens, flower events/exhibitions, memorial gardens and cemeteries, religious gardens, rural garden tourism, rose gardens, and museum gardens. Their study is both supply and demand-oriented, mainly involves the assessment phase of management and regards economic sustainability, but also addresses social sustainability.

Prigioniero et al.'s 2020 article, "Role of historic gardens in biodiversity-conservation strategy: the example of the Giardino Inglese of Reggia di Caserta (UNESCO) (Italy)" [54] presents a field survey 
of the vegetation in the Caserta English garden. Data are georeferenced, and the conservation status of each registered species is cataloged, along with the individual plant's phytosanitary status. An index of germplasm erosion risk (ER) and a priority score allows management to allocate resources so as to best conserve the garden's biodiversity patrimony. This article is supply-oriented, involves the assessment phase of management, and regards environmental sustainability.

\section{Appendix A.4. Private Gardens}

Gullino, Larcher and Devecchi's 2010 article, "The Importance of the Chestnut Cultivation and Its Evolution in the Piedmont Landscape (North-West Italy)" [59] investigates the historical presence of chestnut trees in the Piedmont landscape by comparing archival cartography and documents with a current botanical field survey of private historic estates. The article is supply-oriented, involves the strategic phase of landscape management, and equally regards social and environmental sustainability.

Flinck's 2016 conference paper, "Historic gardens in the center of Stockholm" [73], documents a conservation plan for private historic gardens in a Stockholm neighborhood managed by a private developer. Three case-study kitchen gardens dating back to the 18th-century are also described. The conservation plan establishes general limits and time frames for the historic gardens' management, resulting in the tenants generally maintaining their layout and structure, but replacing the historic flora with lawns and flower bedding. Nonetheless, according to the author, the historic charm of these areas makes them attractive to renters and visitors. The study is supply-oriented, involves the assessment phase of management, and regards social sustainability.

Gao and Dietze-Schirdewahn's 2018 article, "Garden culture as heritage: A pilot study of garden culture conservation based on Norwegian examples" [10] investigates what owners value most in their historic gardens and how these values influence garden heritage conservation. Through a series of interviews with Norwegian owners of heritage gardens, the authors identify the values that they place on their gardens and how they personally identify them as cultural heritage. After identifying "unique" gardens with a snowball strategy, they conduct 21 semi-structured qualitative interviews between 2014-2016. They compare the values expressed by owners to the evaluative principles in historic garden policy documents, showing that the interaction between people and gardens is mostly unconsidered. The authors note that recent heritage conservation theory places greater value on cultural conservation than on the conservation of the physical fabric of heritage, with more attention dedicated to every-day life, skills and craftsmanship. Finally, the authors suggest a new approach of "garden culture conservation", as opposed to garden monument conservation, inspired by ICCROM's living heritage approach [121] and philosophical considerations connecting gardens, eudaimonia (i.e., the state of human flourishing), sustainability and quality of life [10]. The study is supply-oriented, involves the assessment phase of management and regards social sustainability.

\section{References}

1. Cole, G.A. Management Theory and Practice, 6th ed.; Cengage Learning EMEA: Andover, UK, 2003; ISBN 978-1-84480-088-9.

2. Connell, J. Managing gardens for visitors in Great Britain: A story of continuity and change. Tour. Manag. 2005, 26, 185-201. [CrossRef]

3. Accati, E.; Devecchi, M. Il restauro del giardino storico. Italus Hortus 2005, 12, 17-30. Available online: http://www.italushortus.it/phocadownload/review/review_2/02.accati.pdf (accessed on 9 July 2020).

4. Zuelow, E.G.E. A History of Modern Tourism; Macmillan Education UK: London, UK, 2016; ISBN 978-0-230-36965-8.

5. Goetcheus, C.; Mitchell, N. The Venice charter and cultural landscapes: Evolution of Heritage Concepts and Conservation over Time. Chang. Over Time 2014, 4, 338-357. [CrossRef]

6. ICOMOS. International Charter for the Conservation and Restoration of Monuments and Sites (the Venice Charter 1964). Available online: https://www.icomos.org/charters/venice_e.pdf (accessed on 8 September 2020). 
7. Australia/ICOMOS. Burra Charter 1979. Available online: https://australia.icomos.org/wp-content/uploads/ Burra-Charter_1979.pdf (accessed on 8 September 2020).

8. ICOMOS-IFLA. Historic Gardens-The Florence Charter 1981. Available online: https://www.icomos.org/ images/DOCUMENTS/Charters/gardens_e.pdf (accessed on 7 September 2020).

9. Council of Europe. European Landscape Convention. Available online: https://rm.coe.int/ CoERMPublicCommonSearchServices/DisplayDCTMContent?documentId=0900001680080621 (accessed on 7 September 2020).

10. Gao, L.; Dietze-Schirdewahn, A. Garden culture as heritage: A pilot study of garden culture conservation based on Norwegian examples. Urban For. Urban Green. 2018, 30, 239-246. [CrossRef]

11. United Nations. UN Cities-United Nations Sustainable Development Goals. Available online: https: //www.un.org/sustainabledevelopment/cities/ (accessed on 1 October 2020).

12. Cazzani, A.; Zerbi, C.M.; Brumana, R. Management Plans and Web-GIS Software Applications as Active and Dynamic Tools to Conserve and Valorize Historic Public Gardens. ISPRS—Int. Arch. Photogramm. Remote. Sens. Spat. Inf. Sci. 2019, 42, 291-298. [CrossRef]

13. Centre, U.W.H. The Operational Guidelines for the Implementation of the World Heritage Convention. Available online: https://whc.unesco.org/en/guidelines/ (accessed on 8 September 2020).

14. Natural England. Preparing a Heritage Management Plan. Available online: https://assets.publishing. service.gov.uk/government/uploads/system/uploads/attachment_data/file/350304/NE63-preparing-a-heritagemanagement-plan.pdf (accessed on 29 October 2020).

15. Birnbaum, C.A.; Capella Peters, C.; Madigan, K.J. The Secretary of the Interior's Standards for the Treatment of Historic Properties: With Guidelines for the Treatment of Cultural Landscapes; Historic Landscape Initiative (Project); U.S. Department of Interior, National Park Service, Cultural Resource Stewardship and Partnerships, Heritage Preservation Services, Historic Landscape Initiative: Washington, DC, USA, 1996; ISBN 978-0-16-048700-2.

16. Askwith, $\mathrm{C}$. The economic contribution of historic parks, gardens and designed landscapes: A review of existing data and research and recommendations for future research. Cult. Trends 1999, 9, 27-79. [CrossRef]

17. Meda, P.; Rinaldi, G. Management and opening to an extra-university public of university botanical gardens, synthesis of a self evaluation on a questionnaire base. Ital. Bot. 2006, 38, 312-314.

18. Albericci, R. Issues relating to the technical management, the lack of specific skills and the professional training of staff working in botanic gardens and historic parks. Ital. Bot. 2006, 38, 298-300.

19. Boisset, C.M. The Don Wells Memorial Essay, 1979: Management of Historic Gardens-Their Role in the Present and the Future as Public Amenity Areas. Arboric. J. 1980, 4, 34-40. [CrossRef]

20. Thoday, P. Science and Craft in Understanding Historic Gardens and Their Management. In Gardens $\mathcal{E}$ Landscapes in Historic Building Conservation; Harney, M., Ed.; John Wiley \& Sons, Ltd.: Oxford, UK, 2014; pp. 141-148, ISBN 978-1-118-50810-7.

21. Sales, J. Conserving historic gardens. J. Archit. Conserv. 2000, 6, 72-84. [CrossRef]

22. Brine, A.; Feather, J. The information needs of UK historic houses: Mapping the ground. J. Doc. 2010, 66, 28-45. [CrossRef]

23. Counsell, J. An evolutionary approach to digital recording and information about heritage sites. In Proceedings of the 2001 Conference on Virtual Reality, Archeology, and Cultural Heritage-VAST '01, Glyfada, Greece, 28-30 November 2001; ACM Press: Glyfada, Greece, 2001; pp. 33-41, 362. [CrossRef]

24. ICOMOS. The Valletta Principles for the Safeguarding and Management of Historical Cities, Towns and Urban Areas. Available online: http://civvih.icomos.org/sites/default/files/Valletta\%20Principles\%20Book\% 20in\%205\%20languages.pdf (accessed on 9 September 2020).

25. Moher, D.; Liberati, A.; Tetzlaff, J.; Altman, D.G.; The PRISMA Group. Preferred Reporting Items for Systematic Reviews and Meta-Analyses: The PRISMA Statement. PLoS Med 2009, 6, e1000097. [CrossRef] [PubMed]

26. Dempsey, N.; Bramley, G.; Power, S.; Brown, C. The social dimension of sustainable development: Defining urban social sustainability. Sustaint. Dev. 2011, 19, 289-300. [CrossRef]

27. Urban Forestry \& Urban Greening. Available online: https://www.journals.elsevier.com/urban-forestry-andurban-greening (accessed on 24 November 2020).

28. Journal of Cultural Heritage. Available online: https://www.journals.elsevier.com/journal-of-culturalheritage (accessed on 24 November 2020). 
29. Landscape and Urban Planning. Available online: https://www.journals.elsevier.com/landscape-and-urbanplanning (accessed on 24 November 2020).

30. Our Journal-Landscape Research Group. Available online: https://landscaperesearch.org/our-journal/ (accessed on 24 November 2020).

31. ISPRS_Brochure.Pdf. Available online: https://www.isprs.org/publications/brochure/ISPRS_brochure.pdf (accessed on 24 November 2020).

32. Harney, M. (Ed.) Gardens \& Landscapes in Historic Building Conservation; John Wiley \& Sons, Ltd.: Oxford, UK, 2014; ISBN 978-1-118-50810-7.

33. Alves, M.; Vaz, C.; Gomes, A.; Virtuoso, F. Restoration of the Masonry Arch Bridge over Jamor River in the National Palace of Queluz. In Structural Analysis of Historical Constructions; Aguilar, R., Torrealva, D., Moreira, S., Pando, M.A., Ramos, L.F., Eds.; RILEM Bookseries; Springer International Publishing: Cham, Switzerland, 2019; Volume 18, pp. 2483-2491, ISBN 978-3-319-99440-6.

34. Silva, S.; Carvalho, P. Visiting gardens in Portugal: Profiling the historic gardens visit and visitors. In Tourism Innovation: Technology, Sustainability and Creativity; Routledge: London, UK; New York, NY, USA, 2019; pp. 127-147; ISBN 978-036707787-7.

35. Obad Šćitaroci, M.; Marić, M.; Vahtar-Jurković, K.; Knežević, K.R. Revitalisation of Historic Gardens-Sustainable Models of Renewal. In Cultural Urban Heritage; Obad Šćitaroci, M., Bojanić Obad ćŠitaroci, B., Mrđa, A., Eds.; Urban Book Series; Springer: Cham, Switzerland, 2019; pp. 423-441. [CrossRef]

36. Rostami, R.; Lamit, H.; Khoshnava, S.; Rostami, R.; Rosley, M. Sustainable Cities and the Contribution of Historical Urban Green Spaces: A Case Study of Historical Persian Gardens. Sustainability 2015, 7, 13290-13316. [CrossRef]

37. Todt, H.; Herder, J.G.; Dabija, D.-C. The Role of Monument Protection for Tourism. Amfiteatru Econ. 2008, 10, 292-297.

38. Saeed, M.; Qasim, M.; Khan, M.M.; Ali, T. Historic Gardens Can Attract More Visitors by the Provision of More Facilities: A Case Study of Three Mughal Gardens of Pakistan. Pak. J. Agric. Sci. 2017, 54, 45-50. [CrossRef]

39. Luz, I.C.A.; de Paiva, P.D.O.; da Alves, S.F.N.S.C. Train station area gardens: The creation and evolution of Dr. José Esteves Square, in Lavras-MG. Ornam. Hortic. 2018, 23, 432-443. [CrossRef]

40. Gratani, L. Didactic functionality-The Botanical Garden of Rome. Ital. Bot. 2006, 38, 254-257.

41. De Paiva, P.D.O.; de Sousa, R.B.; Carcaud, N. Flowers and gardens on the context and tourism potential. Ornam. Hortic. 2020, 26, 121-133. [CrossRef]

42. Thorne, N. Costing and Contracts for Historic Gardens and Landscapes. In Gardens $\mathcal{E}$ Landscapes in Historic Building Conservation; Harney, M., Ed.; John Wiley \& Sons, Ltd.: Oxford, UK, 2014; pp. 239-246; ISBN 978-1-118-50810-7.

43. Pérez-Urrestarazu, L.; Egea, G.; Ruiz-Alcalá, C.; Roldán-Olmo, F.; Fernández-Cañero, R. Water management assessment in a historic garden: The case study of the Real Alcazar (Seville, Spain). Urban For. Urban Green. 2018, 29, 192-199. [CrossRef]

44. Malinverni, E.S.; Chiappini, S.; Pierdicca, R. A geodatabase for multisource data management applied to cultural heritage: The case study of Villa Buonaccorsi's historical garden. Int. Arch. Photogramm. Remote Sens. Spat. Inf. Sci. 2019, XLII-2/W11, 771-776. [CrossRef]

45. Ciaffi, M.; Alicandri, E.; Vettraino, A.M.; Paolacci, A.R.; Tamantini, M.; Tomao, A.; Agrimi, M.; Kuzminsky, E. Conservation of veteran trees within historical gardens (COVE): A case study applied to Platanus orientalis L. in central Italy. Urban For. Urban Green. 2018, 34, 336-347. [CrossRef]

46. Burford, G.; Hoover, E.; Velasco, I.; Janoušková, S.; Jimenez, A.; Piggot, G.; Podger, D.; Harder, M.K. Bringing the "Missing Pillar" into sustainable development goals: Towards intersubjective values-based indicators. Sustainability 2013, 5, 3035-3059. [CrossRef]

47. James, P. Domains of Sustainability. In Global Encyclopedia of Public Administration, Public Policy, and Governance; Springer: Cham, Switzerland, 2016; pp. 1-17. [CrossRef]

48. Cheng, X.; Van Damme, S.; Li, L.; Uyttenhove, P. Evaluation of cultural ecosystem services: A review of methods. Ecosyst. Serv. 2019, 37, 100925. [CrossRef]

49. Kowarik, I.; Wohlgemuth, J.O. Tulipa sylvestris (Liliaceae) in Northwestern Germany: A non-indigenous species as an indicator of previous horticulture. Pol. Bot. Stud. 2006, 22, 317-331. 
50. Hansen, O.K.; Thomsen, P.; Rasmussen, C.W. DNA markers provide insight about common lime in historical plantings-An example from the Royal Danish Gardens. Urban For. Urban Green. 2014, 13, 543-552. [CrossRef]

51. Oishi, Y. Urban heat island effects on moss gardens in Kyoto, Japan. Landsc. Ecol. Eng. 2019, 15, 177-184. [CrossRef]

52. Gullino, P.; Larcher, F.; Devecchi, M. The importance of the chestnut cultivation and its evolution in the Piedmont landscape (North-West Italy). Acta Hortic. 2010, 866, 37-42. [CrossRef]

53. Arteaga, A.; Malumbres-Olarte, J.; Gabriel, R.; Ros-Prieto, A.; Casimiro, P.; Sanchez, A.F.; Albergaria, I.S.; Borges, P.A.V.; Cardoso, P. Arthropod diversity in two historic gardens in the Azores, Portugal. Biodivers. Data J. 2020, 8. [CrossRef]

54. Prigioniero, A.; Sciarrillo, R.; Spuria, L.; Zuzolo, D.; Marziano, M.; Scarano, P.; Tartaglia, M.; Guarino, C. Role of historic gardens in biodiversity-conservation strategy: The example of the Giardino Inglese of Reggia di Caserta (UNESCO) (Italy). Plant Biosyst. Int. J. Deal. All Asp. Plant Biol. 2020, 1-11. [CrossRef]

55. Maurer, U.; Peschel, T.; Schmitz, S. The flora of selected urban land-use types in Berlin and Potsdam with regard to nature conservation in cities. Landsc. Urban Plan. 2000, 46, 209-215. [CrossRef]

56. Kümmerling, M.; Müller, N. The relationship between landscape design style and the conservation value of parks: A case study of a historical park in Weimar, Germany. Landsc. Urban Plan. 2012, 107, 111-117. [CrossRef]

57. Cavagnero, P.; Revelli, R. Numerical model application for the restoration of the Racconigi Royal Park (CN, Italy). J. Cult. Herit. 2009, 10, 514-519. [CrossRef]

58. Cappelletti, E.M. A historical botanic garden, UNESCO World cultural Heritage: Opportunities and problems. Ital. Bot. 2006, 38, 278-284.

59. Gullino, P.; Devecchi, M.; Larcher, F. New sustainable approach for historical garden restoration: The case study of Ludwig Winter's Gardens in Liguria Region. Acta Hortic. 2020, 9-14. [CrossRef]

60. Nascimbene, J.; Salvadori, O. Lichen recolonization on restored calcareous statues of three Venetian villas. Int. Biodeterior. Biodegrad. 2008, 62, 313-318. [CrossRef]

61. Tisi, F. Making the most of educational experiences in historic and botanical gardens in Trentino. Ital. Bot. 2006, 38, 258-264.

62. Bergande, B.; Markstein, B. A preservation and management plan for the Botanic Garden Berlin-Dahlem. Englera 2013, 30, 145-162.

63. Krosigk, K.V. Preservation and maintenance of historic gardens and parks in West Germany. Landsc. Res. 1987, 12, 18-21. [CrossRef]

64. Khalilnezhad, S.M.R. Principles of integration of the agriculture and pleasure greeneries in Persian gardens. Acta Hortic. 2017, 39-42. [CrossRef]

65. Mahdizadeh, S.; Rajendran, L.P. A renewed approach to conservation policy of historical gardens in Iran. Landsc. Res. 2019, 44, 48-61. [CrossRef]

66. Mahmood, P.; Nasim, S. The Manner of Rehabilitation of Historical Vernacular Gardens (case Study Is Ali Abad Garden in Bojnourd-Iran); Jasienko, J., Ed.; Dolnoslaskie Wydawnictwo Edukacyjne-Dwe: Wroclaw, Poland, 2012; pp. 2744-2749; ISBN 978-83-7125-216-7.

67. Mang, B. The Austrian Federal Gardens and their plant collections-Historical garden monuments, cultural heritage, recreational spaces and tourist attractions. Englera 2013, 30, 137-144.

68. Abdel-Rahman, N.H. Egyptian Historical Parks, Authenticity vs. Change in Cairo's Cultural Landscapes. Procedia-Soc. Behav. Sci. 2016, 225, 391-409. [CrossRef]

69. Vissac, C. Study of a historical garden soil at the Grand-Pressigny site (Indre-et-Loire, France): Evidence of landscape management. J. Cult. Herit. 2005, 6, 61-67. [CrossRef]

70. Wahurwagh, A.; Dongre, A. Burhanpur cultural landscape conservation: Inspiring quality for sustainable regeneration. Sustainability 2015, 7, 932-946. [CrossRef]

71. Burmil, S. Issues in the conservation of gardens in israel: Ramat hanadiv as a case study. Stud. Hist. Gard. Des. Landsc. 2000, 20, 57-68. [CrossRef]

72. Ionescu, R.; Iliescu, A.F.; Dumitrascu, M. Historical Garden as Cultural Identity Mark in Bucharest Urban Landscape-Case Study: The Kiseleff Road and Garden. Acta Hortic. 2010, 851-854. [CrossRef] 
73. Flinck, M. Historic gardens in the center of Stockholm. In Proceedings of the XXIX International Horticultural Congress on Horticulture: Sustaining Lives, Livelihoods and Landscapes(IHC2014): V International Conference on Landscape and Urban Horticulture and International Symposium on Sustainable Management in the Urban Forest, Brisbane, Australia, 17 August 2014; International Society for Horticultural Science: Leuven, Belgium, 2016; Volume 1108, pp. 115-121. [CrossRef]

74. Halbrooks, M.C. The English garden at Stan Hywet Hall and gardens: Interpretation, analysis, and documentation of a historic garden restoration. HortTechnology 2005, 15, 196-213. [CrossRef]

75. Phillips, A. The International Context-The European Landscape Convention. In Gardens E Landscapes in Historic Building Conservation; Harney, M., Ed.; John Wiley \& Sons, Ltd.: Oxford, UK, 2014; pp. 309-320; ISBN 978-1-118-50810-7.

76. Anderson, L.M.; Cordell, H.K. Influence of trees on residential property values in Athens, Georgia (U.S.A.): A survey based on actual sales prices. Landsc. Urban Plan. 1988, 15, 153-164. [CrossRef]

77. Garrod, G.; Pickering, A.; Willis, K. The economic value of botanic gardens: A recreational perspective. Geoforum 1993, 24, 215-224. [CrossRef]

78. Liston-Heyes, C.; Heyes, A. Recreational benefits from the Dartmoor National Park. J. Environ. Manag. 1999, 55, 69-80. [CrossRef]

79. Markwell, S.; Bennett, M.; Ravenscroft, N. The changing market for heritage tourism: A case study of visits to historic houses in England. Int. J. Herit. Stud. 1997, 3, 95-108. [CrossRef]

80. Powe, N.A.; Garrod, G.D.; Willis, K.G. Valuation of urban amenities using an hedonic price model. J. Prop. Res. 1995, 12, 137-147. [CrossRef]

81. Powe, N.A.; Willis, K.G. Benefits received by visitors to heritage sites: A case study of Warkworth Castle. Leis. Stud. 1996, 15, 259-275. [CrossRef]

82. Willis, K.G. Paying for heritage: What price for durham cathedral? J. Environ. Plan. Manag. 1994, 37, $267-278$. [CrossRef]

83. Connell, J. The purest of human pleasures: The characteristics and motivations of garden visitors in Great Britain. Tour. Manag. 2004, 25, 229-247. [CrossRef]

84. Kempiak, J.; Hollywood, L.; Bolan, P.; McMahon-Beattie, U. The heritage tourist: An understanding of the visitor experience at heritage attractions. Int. J. Herit. Stud. 2017, 23, 375-392. [CrossRef]

85. Poria, Y.; Butler, R.; Airey, D. Links between tourists, heritage, and reasons for visiting heritage sites. J. Travel Res. 2004, 43, 19-28. [CrossRef]

86. Catahan, N.; Woodruffe-Burton, H. The view, brew and loo: Perceptions of botanic gardens? J. Place Manag. Dev. 2019, 12, 20-38. [CrossRef]

87. Leiper, N. Tourist attraction systems. Ann. Tour. Res. 1990, 17, 367-384. [CrossRef]

88. Garcia, C.S.G.; Paiva, P.D.O.; Alves, S.F.N.S.C.; Salgado, M.C.R. Transformations in the gardens and landscapes of the historical Traituba's Farm. Ornam. Hortic. 2017, 23, 45-57. [CrossRef]

89. Claval, P. L'étude géographique des parcs et des jardins (A geographical approach of parks and gardens). Bull. l'Assoc. Géogr. Français 1989, 66, 167-175. [CrossRef]

90. Doolittle, W.E. Gardens are us, We are Nature: Transcending Antiquity and Modernity. Geogr. Rev. 2004, 94, 391-404. [CrossRef]

91. Fallahi, E. Horticulture in Iran Can Be an Alternative to Petroleum and a Major Source of International Business with Unique Potential and Challenges. HortScience 2017, 52, 1145-1147. [CrossRef]

92. Fallahi, E.; Fallahi, P.; Mahdavi, S. Ancient urban gardens of persia: Concept, history, and influence on other world gardens. HortTechnology 2020, 30, 6-12. [CrossRef]

93. Heywood, V.H. The future of plant conservation and the role of botanic gardens. Plant Divers. 2017, 39, 309-313. [CrossRef]

94. Powledge, F. The Evolving Role of Botanical GardensHedges against extinction, showcases for botany? BioScience 2011, 61, 743-749. [CrossRef]

95. Krishnan, S.; Novy, A. The role of botanic gardens in the twenty-first centuryy. CAB Rev. Perspect. Agric. Vet. Sci. Nutr. Nat. Resour. 2016, 11. [CrossRef]

96. Towse, R. A Textbook of Cultural Economics, 2nd ed.; Cambridge University Press: New York, NY, USA, 2019; ISBN 978-1-108-42168-3. 
97. Mazza, I. 4. Organization and Decision-making in the Heritage Sectori in Sicily. In The Economics of Heritage: A Study in the Political Economy of Culture in Sicily; Rizzo, I., Towse, R., Eds.; Edward Elgar Pub: Cheltenham, UK; Northampton, MA, USA, 2002; pp. 48-62; ISBN 978-1-84376-041-2.

98. Rizzo, I.; Towse, R. The Economics of Heritage: A Study in the Political Economy of Culture in Sicily; Edward Elgar Pub: Cheltenham, UK; Northampton, MA, USA, 2002; ISBN 978-1-84376-041-2.

99. UNESCO. Recomendation on the Historic Urban Landscape. Available online: https://whc.unesco.org/ uploads/activities/documents/activity-638-98.pdf (accessed on 8 September 2020).

100. ICOMOS-IFLA. Document on Historic Urban Parks. 2017. Available online: https://www.icomos.org/ images/DOCUMENTS/General_Assemblies/19th_Delhi_2017/Working_Documents-First_Batch-August_ 2017/GA2017_6-3-2_HistoricUrbanPublicParks_EN_final20170730.pdf (accessed on 9 September 2020).

101. EPIC. About Botanic Gardens. Available online: https://www.bgci.org/about/about-botanic-garden/ (accessed on 28 October 2020).

102. US/ICOMOS. Natchitos Declaration on Heritage Landscapes. Available online: https://usicomos.org/wpcontent/uploads/2019/12/213natchitoches.pdf (accessed on 8 September 2020).

103. ICOMOS. The Nara Document on Authenticity (1994). Available online: https://www.icomos.org/charters/ nara-e.pdf (accessed on 8 September 2020).

104. Tempesta, T. Benefits and costs of urban parks: A review. Aestimum 2016, 127-143. [CrossRef]

105. Tempesta, T. People's Preferences and Landscape Evaluation in Italy: A review. New Medit. 2014, 13, 50-59. Available online: https://newmedit.iamb.it/bup/wp-content/uploads/2018/06/971_50tempesta.pdf (accessed on 1 December 2020).

106. Balding, M.; Williams, K.J.H. Plant blindness and the implications for plant conservation. Conserv. Biol. 2016, 30, 1192-1199. [CrossRef] [PubMed]

107. Sanders, D.L.; Ryken, A.E.; Stewart, K. Navigating nature, culture and education in contemporary botanic gardens. Environ. Educ. Res. 2018, 24, 1077-1084. [CrossRef]

108. Zopiatis, A.; Melanthiou, Y. The celebrity chef phenomenon: A (reflective) commentary. IJCHM 2019, 31, 538-556. [CrossRef]

109. Neonato, F.; Colaninno, B.; Tomasinelli, F. Green Ecosystem Services: TEV as tool to take decision for urban Planning. Econ. Policy Energy Environ. 2019, 85-112. [CrossRef]

110. Brandt, A.; Rohde, M. Sustainable Marketing for Historic Gardens. Gard. Hist. 2007, 35, 131-145.

111. Benfield, R.W. "Good things come to those who wait": Sustainable tourism and timed entry at Sissinghurst Castle Garden, Kent. Tour. Geogr. 2001, 3, 207-217. [CrossRef]

112. Benfield, R. Garden Tourism; CAB International: Oxfordshire, UK; Boston, MA, USA, 2013; ISBN 978-1-78064-195-9.

113. Tempesta, T. Degradation of the Palladian landscape. Aestimum 2018, 109-130. [CrossRef]

114. Harney, M. Introduction. In Gardens E Landscapes in Historic Building Conservation; Harney, M., Ed.; John Wiley \& Sons, Ltd.: Oxford, UK, 2014; pp. xv-xxiii; ISBN 978-1-118-50810-7.

115. Millennium Ecosystem Assessment (Program). Ecosystems and Human Well-Being: Synthesis; Island Press: Washington DC, USA, 2005; ISBN 978-1-59726-040-4.

116. Seiler, J. Management Regimes for Lawns and Hedges in Historic Gardens. Ph.D. Thesis, University of Gothenburg, Gothenburg, Sweden, 2020. Available online: https://gupea.ub.gu.se/handle/2077/62813 (accessed on 30 October 2020).

117. UNTWO. World Tourism Barometer May 2020 Special focus on the Impact of COVID-19. Available online: https://webunwto.s3.eu-west-1.amazonaws.com/s3fs-public/2020-05/Barometer_May2020_ full.pdf (accessed on 29 October 2020).

118. Ugolini, F.; Massetti, L.; Calaza-Martínez, P.; Cariñanos, P.; Dobbs, C.; Ostoić, S.K.; Marin, A.M.; Pearlmutter, D.; Saaroni, H.; Šaulienè, I.; et al. Effects of the COVID-19 pandemic on the use and perceptions of urban green space: An international exploratory study. Urban For. Urban Green. 2020, 56, 126888. [CrossRef]

119. Bandarin, F.; van Oers, R. The Historic Urban Landscape: Managing Heritage in an Urban Century; Wiley Blackwell: Chichester, UK; Hoboken, NJ, USA, 2012; ISBN 978-0-470-65574-0.

120. UNESCO. Vienna Memorandum on "World Heritage and Contemporary Architecture-Managing the Historic Urban Landscape" and Decision 29 COM 5D. Available online: https://whc.unesco.org/archive/2005/ whc05-15ga-inf7e.pdf (accessed on 16 September 2020). 
121. International Centre for the Study of the Preservation and Restoration of Cultural Property; Sarah Court; Gemini Wijesuriya People-Centred Approaches to the Conservation of Cultural Heritage: Living Heritage. Available online: https://www.iccrom.org/sites/default/files/PCA_Annexe-2.pdf (accessed on 25 September 2020).

Publisher's Note: MDPI stays neutral with regard to jurisdictional claims in published maps and institutional affiliations.

(C) 2020 by the authors. Licensee MDPI, Basel, Switzerland. This article is an open access article distributed under the terms and conditions of the Creative Commons Attribution (CC BY) license (http://creativecommons.org/licenses/by/4.0/). 